\title{
RESEARCH
}

Open Access

\section{The analysis of the degree of 10-13-year- old children's nutrition, dietary habits and physical activity in the selected rural and urban areas of Silesian Province (Poland)}

Paweł Jonczyk ${ }^{1 *}$ D, Magdalena Potempa-Jeziorowska ${ }^{1}$, Elżbieta Świętochowska ${ }^{2}$ and Marek Kucharzewski ${ }^{1}$

\begin{abstract}
Background: The nutrition disorders in the children's population, in the form of malnutrition, as well as overweight and obesity constitute a significant clinical problem in the contemporary world. As a result of the improper way of children's nutrition, their physical and mental development becomes dysfunctional, which leads in their adult life to serious health consequences, among others, complications of cardiovascular system, metabolic and endocrinological and disorders, improper development of osteoarticular system and mental diseases and social withdrawal.

Results: Five hundred eighty-nine parents of children aged 10-13 participated in the survey questionnaire, where 304 respondents were constituted by girls (51.61\%); however, the remaining 285 people were represented by boys (48.39\%). It turned out that overweight and obesity concern approximately $44 \%$ of respondents; however, approximately $22 \%$ of children have too low body weight in relation to age and sex. While analysing dietary habits, it was observed that main meals are not consumed by all children; breakfast is consumed by approximately $90 \%$ of respondents, packed lunch just by $70 \%$ and lunch and supper by $90 \%$ of respondents. In the course of subsequent analyses, it turned out that over $3 / 4$ of respondents declared that their child drinks mineral water every day, only approximately $44 \%$ of them drink milk every day; however, almost $18 \%$ of children reach for sweet drinks. Children eat sweet or salty snacks too often (over 55\% every day or several times a week), resigning from consuming fruit and vegetables (just half of respondents every day), fish and brown bread (below 30\% of children eat these products less than once a week); every fifth child dedicates less than $3 \mathrm{~h}$ to physical activity, $39 \%$ of respondents do exercise from 3 to $5 \mathrm{~h}$ a week, the next $25 \%$ from 5 to $10 \mathrm{~h}$.

(Continued on next page)
\end{abstract}

\footnotetext{
* Correspondence: pawel jonczyk@o2.pl

${ }^{1}$ Chair and Department of Descriptive and Topographic Anatomy, Faculty of

Health Sciences in Zabrze, Medical University of Silesia in Katowice, UI.

Jordana 19, 41-808 Zabrze, Poland

Full list of author information is available at the end of the article
}

\section{Springer Open}

(c) The Author(s). 2021 Open Access This article is licensed under a Creative Commons Attribution 4.0 International License, which permits use, sharing, adaptation, distribution and reproduction in any medium or format, as long as you give appropriate credit to the original author(s) and the source, provide a link to the Creative Commons licence, and indicate if changes were made. The images or other third party material in this article are included in the article's Creative Commons licence, unless indicated otherwise in a credit line to the material. If material is not included in the article's Creative Commons licence and your intended use is not permitted by statutory regulation or exceeds the permitted use, you will need to obtain permission directly from the copyright holder. To view a copy of this licence, visit http://creativecommons.org/licenses/by/4.0/. 
(Continued from previous page)

Conclusions: It was observed in the analysed population that over half of them struggle with the degree of nutrition disorders in the form of overweight and obesity or malnutrition. We may conclude, based on the obtained results, that children have inappropriate dietary habits, consuming too small quantities of fruit and vegetables, brown bread, fish and drinking improper quantities of water and milk. Repeatedly, they replace these full-value products by consuming sweets and salty snacks and by drinking sweet drinks, they also more and more often reach for processed food in fast food bars. What is worrying, it was also observed that in the analysed population, children dedicate too little of their free time to physical activity and additional physical activities.

Keywords: Disorders' degree of nutrition, School children, Obesity, Overweight, Dietary habits

\section{Background}

Disorders in the nutrition degree and their health, economic and social aftermaths among adults as well as in the children's population constitute one of the main medical problems of the contemporary world. A suitable diet, optimal in terms of quantity and quality of consumed food, conditions proper functioning of a given organism. This diet is particularly important in the case of children whose proper nutrition is crucial for their suitable growth and development since the first days of their lives. Following a balanced diet is not an easy task. It should consist of diverse food and contain a suitable quantity of proteins, carbohydrates, fats, vitamins and water $[1,2]$. In accordance with the report International Obesity Task Force (IOTF), 155 million children in the world, being in their school age, are overweight or obese, out of whom from 30 to 45 million comprise children and youth aged 5-17, and 22 million are obese children below the age of 5 [3]. On the one hand, malnutrition, occurring as a result of deficits of nutrients and vitamins and minerals in the developing countries, on the other hand, overweight and obesity, being the main aftermath of hyperalimentation, inappropriately balanced diet and inadequate physical activity-cause numerous health complications. The results of overweight and obesity among children and adults affect many organs. The most frequently enumerated ones comprise, most of all, endocrinological complications (e.g. insulin resistance, type 2 diabetes, premature puberty, polycystic ovary syndrome, hypogonadism), cardiovascular (among others, lipid metabolism disorders, arterial hypertension, coagulopathy, vascular endothelium dysfunction), respiratory (sleep apnoea syndrome, bronchial asthma, exercise intolerance), gastrointestinal (e.g. gastroesophageal reflux disease, hepatic steatosis, cholelithiasis, stool constipations), renal (among others, glomerulosclerosis), musculoskeletal (spine pain, skeleton fractures, platypodia, femoral epiphysis) and psychosocial (e.g. low self-esteem, fears and phobias, depressive syndromes, nutrition disorders-bulimia, anorexia, social isolation, worsening learning outcomes) [4-6]. Malnutrition is one of the most common causes of growth disorders in children or low body mass in adults. Being the consequence of longterm energy deficit, it causes progressive tissue wasting, biochemical changes, functional disorders and, finally, clinical symptoms. Due to dynamic development of children at school age, food deficiencies may rapidly cause functional disorders of the immune system, lower the cardiorespiratory performance and decrease basic metabolism. Moreover, micro- and macronutrient deficiencies can cause, among others, iron-deficiency anaemia, endemic goitre or disorders in skeleton formation and decreased peak bone mass. Apart from having medical consequences, these two phenomena, i.e. malnutrition and excessive body mass, are also problematic for children in the psychological and social aspects [2]. The authors of this paper decided to define the nutrition degree and potential disorders in the nutrition degree among children aged 10-13 in the Silesian Province (Poland) and to conduct the analysis of their dietary habits and physical activity.

\section{Methods}

The studies were conducted in the years 2018-2019 in the group of parents of the children aged 10-13 in the selected primary schools in the Silesian Province, obtaining the previous acceptance from the headmasters of the schools participating in the studies. The respondents were handed in 1000 paper research questionnaires, containing 40 questions with the option of the selection of one or several responses, depending on the kind of question. The research questionnaire was applied to evaluate the consumption frequency of meals by children, of food products and physical activity, which was designed based on the available food frequency questionnaires (FFQ), prepared by the team of Behavioural Nutrition Conditions, Science Committee of Human Nutrition, Polish Academy of Science and on own observations from the available medical literature. The questions mainly concerned anthropometric data, family structure, economic conditions, dietary habits, children's physical activity and parents. The survey questionnaires were filled in by the 
children's parents at parent-teacher meetings after the preliminary instructions of the authors of the studies. Five hundred eighty-nine questionnaires were qualified for the statistical analysis; the forms incompletely or erroneously filled in were rejected. All analysed children were composed of 304 girls (51.61\%); the remaining part was composed of 285 people-boys (48.39\%). The detailed characteristics of the research group are described in Table 1.

It was decided to verify in the project, based on the calculated values of body mass index (BMI) compared to centile norms generated on the basis of the results of multicentre study OLAF conducted in Poland in the years 2007-2009, what the current nutrition degree is observable in the analysed population of children with the evaluation of dietary habits and children's physical activity. The statistical analyses were conducted with the application of IBM SPSS Statistics package in version 25 .

\section{Results}

\section{Demographic data}

Nearly $88 \%$ of respondents came from complete families, $11.66 \%$ from single-parent families; however, two children were under the care of a foster family. The most, that is $58.57 \%$, of the interviewed parents had two children, $19.02 \%$ was constituted by families with one offspring and approximately $22 \%$ of the interviewed children came from multi-children families (defined as families with three or more children). The average age of mothers participating in the study was $39.22 \pm 4.78$ years (with the youngest and the oldest age noted in the study, amounting respectively to 28 and 55 years old); on the other hand, as for fathers, their age amounted to $41.66 \pm$ 5.53 years (with the youngest and the oldest age noted in the study, amounting respectively to 27 and 65 years old). The structure of parents' education turned out to be varied. Most parents had secondary education (39.39\% of women and $40.10 \%$ of men). Higher education prevails among women (42.26\%) and secondary education among men. $53.18 \%$ of respondents declare that they live in a city, $17.38 \%$ declare the country as their place of residence and the remaining respondents (29.44\%) live in towns. Figure 1 presents the employment structure in the analysed families. Except for that,

Table 1 Age of the investigated group

\begin{tabular}{lll}
\hline Age group & Boys & Girls \\
\hline 10 & 116 & 116 \\
11 & 57 & 83 \\
12 & 76 & 70 \\
13 & 36 & 35 \\
Total & 285 & 304 \\
\hline
\end{tabular}

\section{The employment structure in the analysed families}

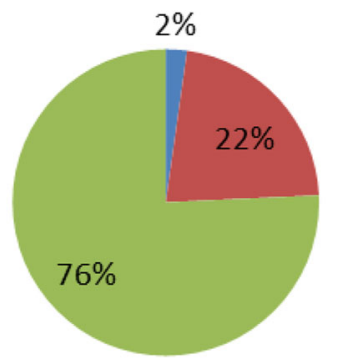

- Lack

One

Two

Fig. 1 The employment structure in the analysed families

the obtained data indicate that $78.3 \%$ of parents have a proper body weight; however, $21.7 \%$ of them struggle with the problem of overweight or obesity.

\section{Nutrition degree of the analysed children}

Based on the anthropometric measurements and calculated BMI indexes, the nutrition degree of interviewed children was defined in accordance with the European norms. It was assumed that underweight concerns a child whose BMI index is below 5th centile for a given population in terms of age and sex, BMI index was defined as overweight in the range 85th-95th centile and obesity over 95th centile. The manner of specifying the nutritional status in the analysed group of children was presented in Fig. 2.

The problem of obesity concerned $26.35 \%$ of the analysed children; on the other hand, overweight affected additionally $16.44 \%$ of the population. The underweight state in the analysed group of children was observed among $21.84 \%$ of respondents. Proper body weight in relation to height and sex was noted in over 35\% of interviewees. Nutritional status of children was presented in Table 2.

\section{The analysis of dietary habits in the analysed children's population}

After conducting the analysis of the basic descriptive statistics, the analyses of frequency were conducted, concentrating, in the first instance, on dietary habits of children aged 10-13. In accordance with the obtained

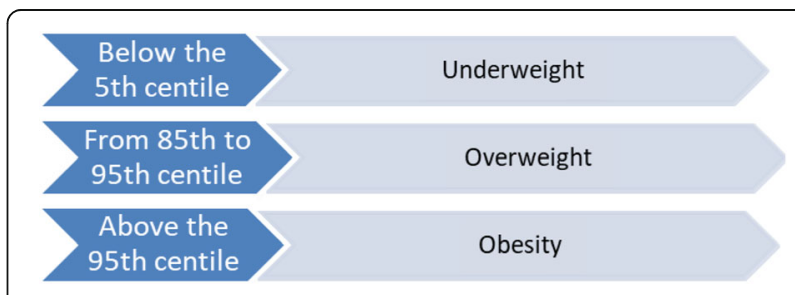

Fig. 2 Manner of specifying the nutritional status of children 
Table 2 Nutritional status of children in a given age group

\begin{tabular}{lllll}
\hline $\begin{array}{l}\text { Age } \\
\text { group }\end{array}$ & \multicolumn{4}{l}{ Level of nutrition } \\
\cline { 2 - 5 } & Obesity & Overweight & Normal weight & Malnutrition \\
\hline 10 & $25.43 \%$ & $13.79 \%$ & $49.57 \%$ & $11.21 \%$ \\
11 & $29.29 \%$ & $21.43 \%$ & $32.86 \%$ & $16.42 \%$ \\
12 & $25.34 \%$ & $16.44 \%$ & $29.45 \%$ & $28.77 \%$ \\
13 & $25.35 \%$ & $14.08 \%$ & $29.58 \%$ & $30.99 \%$ \\
Total & $26.35 \%$ & $16.44 \%$ & $35.37 \%$ & $21.84 \%$ \\
\hline
\end{tabular}

data, the vast majority of parents ( $89.8 \%$ of interviewees) declared that their child eat breakfast every day. $6.9 \%$ of respondents acknowledged that their offspring eat breakfast several times a week. A small percentage was constituted by people, who stated that their child eats breakfast once a week ( $0.9 \%$ of interviewees), less than once a week $(0.5 \%$ of interviewees) or he/she does not it breakfast at all $(0.2 \%$ of interviewees). Twelve interviewees (1.8\% of respondents) left the question unanswered. The division of the interviewees in terms of the regularity of breakfast consumption was presented in Fig. 3.

Most children (70.7\% of interviewees) consume their packed lunch every day. $17.7 \%$ of interviewees indicated that their child eats his/her packed lunch several times a week. The remaining parents acknowledged that their offspring consume his/her packed lunch once a week $(0.2 \%$ of interviewees), less than once a week $(1.4 \%$ of interviewees) or they do not consume his/her packed lunch at all (1.4\% of interviewees). $7.6 \%$ of respondents did not provide any answer. The results were presented in Fig. 4.

Almost all parents (97.6\% of interviewees) declared that their child consumes lunch every day. $1.2 \%$ of children eat lunch several times a week. The remaining interviewees did not express an opinion in relation to a given question. The conducted studies indicate that the vast majority of children (91.8\% of interviewees) eat super every day. $5.0 \%$ of children eat super several times

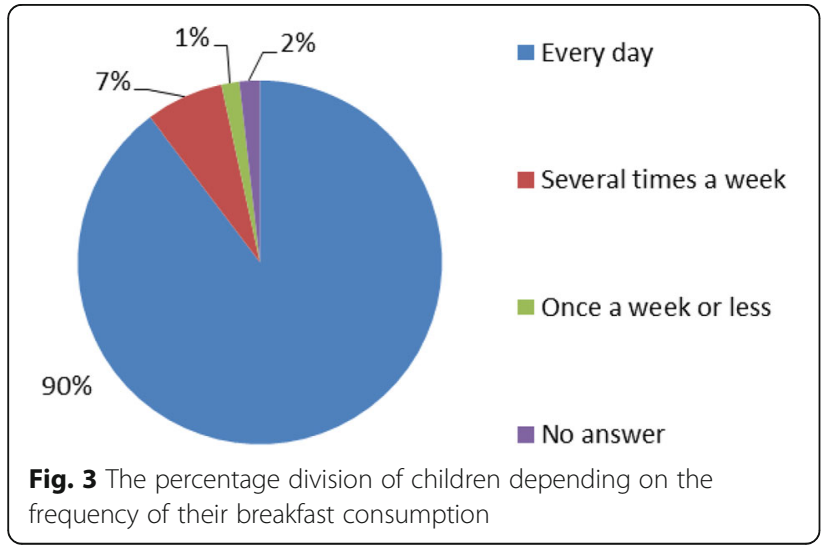

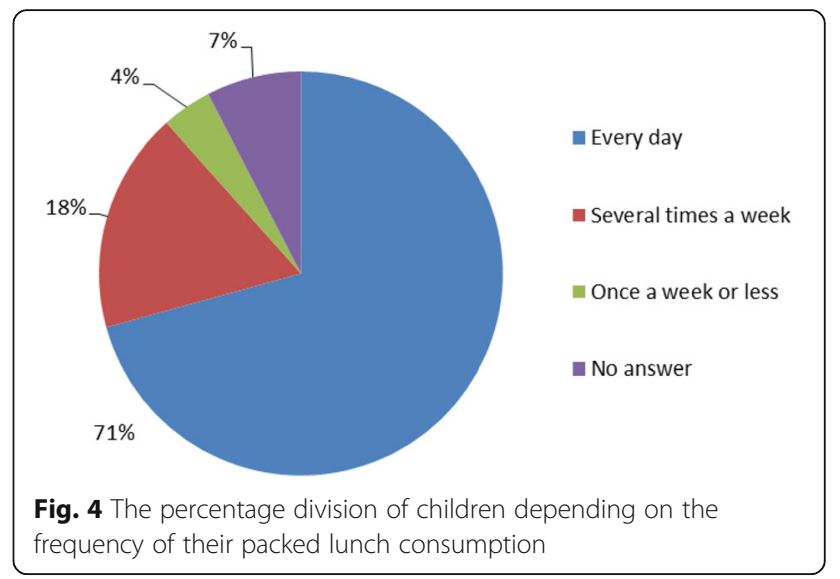

a week. A small percentage of respondents was constituted by parents, who admitted that their offspring eat supper once a week ( $0.3 \%$ of interviewees), less than once a week $(0.2 \%$ of interviewees) or never $(0.2 \%$ of interviewees). $2.6 \%$ of parents left the question unanswered. The subsequent data, also obtained by means of frequency analysis, demonstrate how often children aged 10-13 consume specific products, such as, e.g. milk, meat, fish or salty snacks or sweets. Most parents believed their child consumes milk and/or dairy products every day (44.1\% of interviewees) or several times a week (39.3\% of interviewees). $6.4 \%$ of parents acknowledged that their offspring reaches for dairy products once a week. A small percentage was constituted by children drinking milk and/or consuming dairy products less than once a week (2.7\% of interviewees) or never (2.0\% of interviewees). $5.5 \%$ of respondents did not provide any answer. The results were presented in Fig. 5.

Over $3 / 4$ of respondents (75.6\% of respondents) declared that their child drinks mineral water every day. $12.7 \%$ of adolescents aged $10-13$ reach for mineral water several times a day. The remaining people drink a given product once a week (2.0\% of interviewees), less than

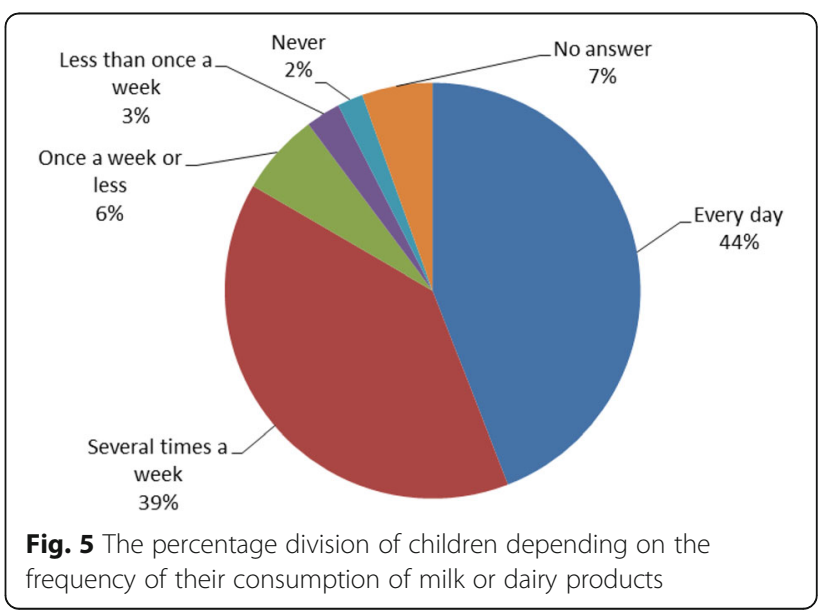


once a week ( $2.1 \%$ of interviewees) or never ( $1.2 \%$ of interviewees). $6.4 \%$ of interviewees did not answer the question related to the frequency of drinking mineral water by their children. The results of the analyses were presented in Fig. 6.

The frequency of consumption of sweet drinks in the analysed group was definitely lower than the frequency of consumption of mineral water. In accordance with the obtained results, $17.7 \%$ of parents admitted that their offspring drink sweet drinks every day. $34.3 \%$ of interviewees claimed that their child reaches for sweet drinks several times a week. The remaining part was constituted by people declaring that their child consumes sweet drinks once a week on average $(18.9 \%$ of interviewees) or less than once a week (16.2\% of interviewees). A small percentage was constituted by children who never drink sweet drinks (2.0\% of interviewees). $11.0 \%$ of interviewees left the question unanswered. The obtained results were presented in a tabular form as well (Table 3).

Almost half of the children aged $10-13$ (47.7\% of interviewees) consume fish once a week. $29.1 \%$ of interviewees claimed that fish is consumed by their children less than once a week. The part of respondents declared, on the other hand, that their offspring eat fish several times a week (6.4\% of respondents) or every day (2.0\% of respondents). $6.9 \%$ of children in a given age group do not eat fish at all. $7.9 \%$ of respondents did not refer to this question. We may conclude, based on the obtained results, that children aged 10-13 occasionally consume brown bread. Most respondents indicated that their offspring eat brown bread less than once a week $(26.8 \%$ of respondents) or several times a week (23.6\% of respondents). $13.4 \%$ of children reach for brown bread once a week; however, slightly less (11.4\% of respondents) eat brown bread every day. $15.5 \%$ of parents admitted that their offspring do not eat brown bread at all. 9.1\% of

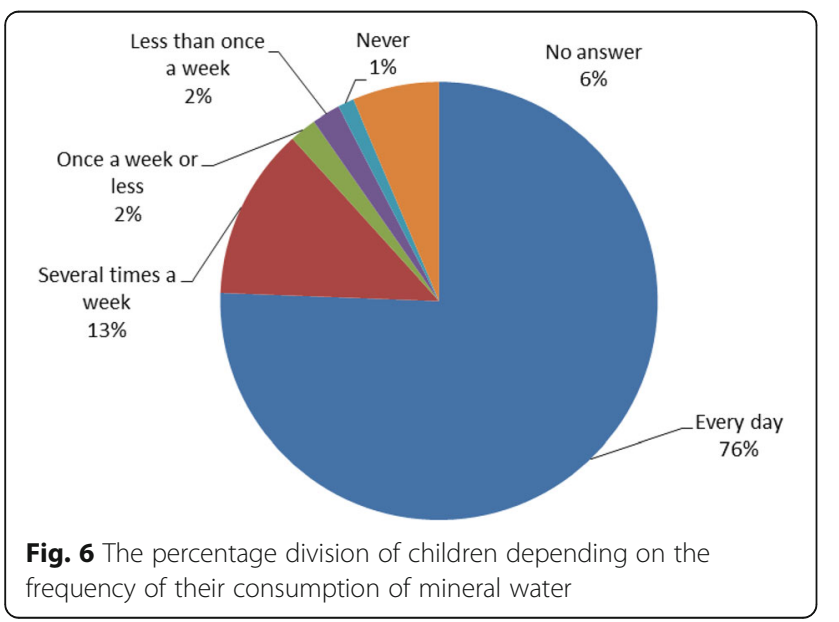

Table 3 The percentage division of children aged 10-13 depending on the frequency of their consumption of sweet drinks

\begin{tabular}{llll}
\hline & $\boldsymbol{n}$ & \% & \% of valid answers \\
\hline Every day & 116 & 17.7 & 19.9 \\
Several times a week & 225 & 34.3 & 38.5 \\
Once a week & 124 & 18.9 & 21.2 \\
Less than once a week & 106 & 16.2 & 18.2 \\
Never & 13 & 2.0 & 2.2 \\
No answer & 72 & 11.0 & - \\
\hline
\end{tabular}

respondents did not provide any answer. The results were presented in Fig. 7.

The vast majority of parents (69.5\%) admitted that their offspring eat meat several times a week. $17.8 \%$ of interviewees declared that their children consume meat every day. A small percentage of children was constituted by children who eat meat once a week ( $4.3 \%$ of interviewees), less than once a week ( $0.6 \%$ of interviewees) or never $(0.4 \%) .6 .9 \%$ of respondents did not refer to the question (Table 4).

The interesting results were obtained by analysing the frequency of consumption of salty snacks or sweets by children. Exactly $14.2 \%$ of children consume salty snacks or sweets every day. Significantly more $(41.3 \%$ of interviewees) reach for this type of snacks several times a week. The remaining children consume salty snacks/ sweets once a week (17.2\% of interviewees) or less than once a week (16.3\% of interviewees). $1.2 \%$ of children do not eat salty snacks/sweets at all. $9.8 \%$ of respondents did not provide any answer (Fig. 8).

Over half of parents $(52.1 \%$ of respondents) declared that their child eats fruit or vegetables every day. 39.2\% of interviewees acknowledged that these products are consumed by their offspring several time a week. A small percentage was constituted by respondents who

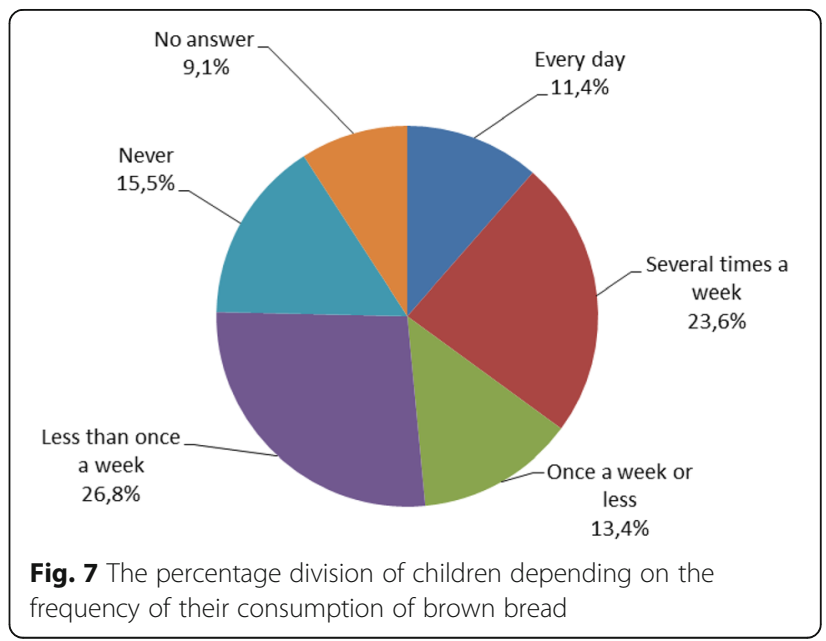


Table 4 The percentage division of children aged 10-13 depending on the frequency of their consumption of meat

\begin{tabular}{llll}
\hline & $\boldsymbol{n}$ & \% & \% of valid answers \\
\hline Every day & 117 & 17.8 & 19.1 \\
Several times a week & 456 & 69.5 & 74.6 \\
Once a week & 28 & 4.3 & 4.6 \\
Less than once a week & 6 & 0.9 & 1.0 \\
Never & 4 & 0.6 & 0.7 \\
No answer & 45 & 6.9 & -
\end{tabular}

admitted that their child eats fruit/vegetables once a week ( $3.0 \%$ of interviewees), less than once a week ( $1.2 \%$ of interviewees) or never ( $0.6 \%$ of interviewees). $3.8 \%$ of interviewees left the question unanswered. $62.3 \%$ of parents declared that their children use fast-food bars less than once a month. $30.2 \%$ of interviewees claimed that their offspring consume a meal in this kind of bars less than once a week. The remaining respondents indicated that their children use fast-food bars once a week (5.5\% of interviewees) or several time a week $(0.8 \%$ of interviewees). Eight people (1.2\% of interviewees) did not answer the question. In the last question related to dietary habit, it was verified what products are most often bought by children aged 10-13 in school shops. In accordance with the data presented in Table 5, most children at this age $(41.2 \%$ of interviewees) do not buy anything in school shops. Among children, who use school shops, the highest percentage was constituted by people buying "something sweet" (e.g. wafer biscuits, buns, sweets, chocolate) (13.9\% of interviewees). The part of parents indicated that their child most often buys salty snacks (e.g. crisps, salt sticks) (7.6\% of interviewees), mineral water (7.2\% of interviewees) or other products not mentioned in the survey questionnaire (5.9\% of interviewees). Sweet drinks (e.g. Coca-Cola) and fruit/vegetables $(0.8 \%$ of interviewees $)$ are the most rarely bought products in the analysed group. What is

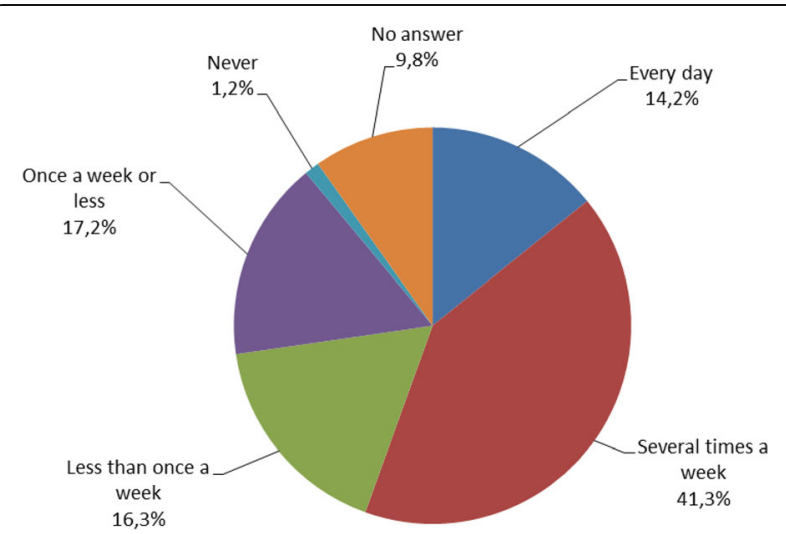

Fig. 8 The percentage division of children depending on the frequency of their consumption of salty snacks or sweets interesting, as many as $22.0 \%$ of interviewees left the question unanswered, which may suggest that their parents are not fully aware what their children spend their money on in the school shops.

Over $1 / 3$ of the interviewed parents stated that the distance between a place of residence and a school their child attends amounts to $500 \mathrm{~m}$, the next $30 \%$ described this distance as $500-1000 \mathrm{~m}$. The obtained results were presented in Fig. 9.

In Fig. 10, on the other hand, the results related to the everyday way of getting to school by the analysed children were presented. It turns out that over $70 \%$ of children go to school on foot; however, every fifth child is transported to school by their parents by car.

The interviewees were also asked about the way of spending free time by their children. Every fourth parent declares a regular sports practice by their child, the next $45 \%$ of children spend their free time outside and only $30 \%$ of them prefer a passive relaxation. The results were graphically presented in Fig. 11. In the questionnaire, there was also a question: Does your child practise any sport with their parent(s)? We obtained a positive answer from only $37.15 \%$ of interviewees. $63 \%$ of parents declare that additional extracurricular classes requiring physical activity are organised in the educational institution which their child goes to. Unfortunately, only slightly over $26 \%$ of children take advantage of this opportunity. Children also very rarely use sports facilities (e.g. a swimming pool, a sports hall, a football pitch) located near their homes. The results were presented in Fig. 12.

The last question related to physical activity is the issue of average time dedicated by children within a week period for active relaxation and physical exercises. Every fifth child dedicates less than $3 \mathrm{~h}$ for physical activity, 39\% of interviewees practice from 3 to $5 \mathrm{~h}$ a week and the next $25 \%$ from 5 to $10 \mathrm{~h}$ (Fig. 13).

Based on the obtained data, it was verified as well if the frequency of the use of sports facilities by children influences the BMI index indicated by them. The results obtained based on the Kruskal-Wallis test demonstrate that children aged 10-13 do not differ statistically significantly from each other in terms of body mass index, although they often use the sports facilities. The results of the analyses were presented in Table 6 .

It was also decided to analyse, in this article, the correlations between body mass index (BMI) and the children's dietary habits. Thus, the analysis of the correlation with Spearman's rho coefficient was conducted. The calculations were carried out in the groups divided in terms of age and sex. The obtained results demonstrate that the frequency of meal consumption: breakfast, packed lunch, dinner and supper per week in a group of girls does not correlate with body mass index. In a group 
Table 5 The percentage division of children aged 10-13 depending on the most often bought article in a school shop

\begin{tabular}{llll}
\hline & $\boldsymbol{n}$ & \% & \% of valid answers \\
\hline "Something sweet" (e.g. wafer biscuits, buns, sweets, chocolate) & 91 & 13.9 & 17.8 \\
Salty snacks (e.g. crisps, salt sticks) & 50 & 7.6 & 9.8 \\
Sweet drinks (e.g. Coca-Cola) & 10 & 1.5 & 2.0 \\
Mineral water & 47 & 7.2 & 9.2 \\
Fruit/vegetables & 5 & 0.8 & 1.0 \\
A child does not buy anything in a school shop & 270 & 41.2 & 52.7 \\
Other product & 39 & 5.9 & 7.6 \\
No answer & 144 & 22.0 & - \\
\hline
\end{tabular}

of boys, however, one significant correlation between body mass index and the frequency of breakfast consumption was observed. This correlation occurs only among 12-year-olds; its strength is, however, rather weak. In a group of 12- and 13-year-old girls and among 11- and 13-year-old boys, BMI was not correlated with the frequency of dinner consumption due to the provision of too homogeneous responses in these age groups. The obtained results were demonstrated in the table below (Table 7).

The corresponding analyses were conducted to investigate the correlation between BMI and the consumption frequency of the specific food products: milk, water, sweet drinks, fish, brown bread, meat, salty snacks/ sweets and fruit/vegetables. It turned out that only the single significant correlations between BMI and the consumption of the specific products occur. In a group of girls aged 10 and 13, it was observed that BMI statistically and significantly correlates with the frequency of meat consumption. The direction of correlations in both groups is opposite, however. What is surprising, the negative weak correlation is observed among 10-yearlold girls, which means that along with the increase in the frequency of meat consumption, BMI level decreases (in other words, the more frequently meat is consumed,

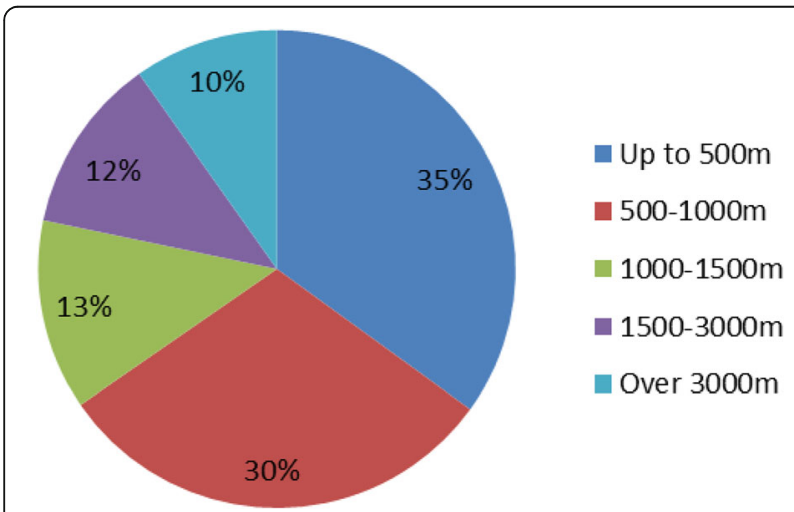

Fig. 9 The percentage division of children aged depending on the distance between home and school the lower the BMI result is among 10-year-old girls). Among 13-year-old girls, the moderate positive correlation occurs: the more frequently meat is consumed, the higher the BMI indicator. In addition, in a group of 10 year-old girls, the weak negative correlation was observed between BMI and the consumption frequency of brown bread, which means, that the more rarely brown bread is consumed, the BMI level is higher. Among 13year-old girls, BMI additionally correlated with the consumption of sweet drinks. The more frequently sweet drinks are consumed in this age group, the BMI indicator is higher. This correlation is moderate. In a group of 10 -year-old boys, the statistically significant positive correlation was observed between BMI and the consumption frequency of fruit and vegetables; however, this correlation was very weak. In addition, the weak positive correlation between BMI and the consumption frequency of milk was observed in a group of 11-year-old boys-the more frequently milk was consumed, the higher the BMI level was. Among 12-year-old boys, however, the significant correlations occurred between BMI and the consumption frequency of water. As it turned out, the BMI level was decreasing along with the consumption frequency of water in a group of 12-yearold boys. The described results are listed in Table 8 .

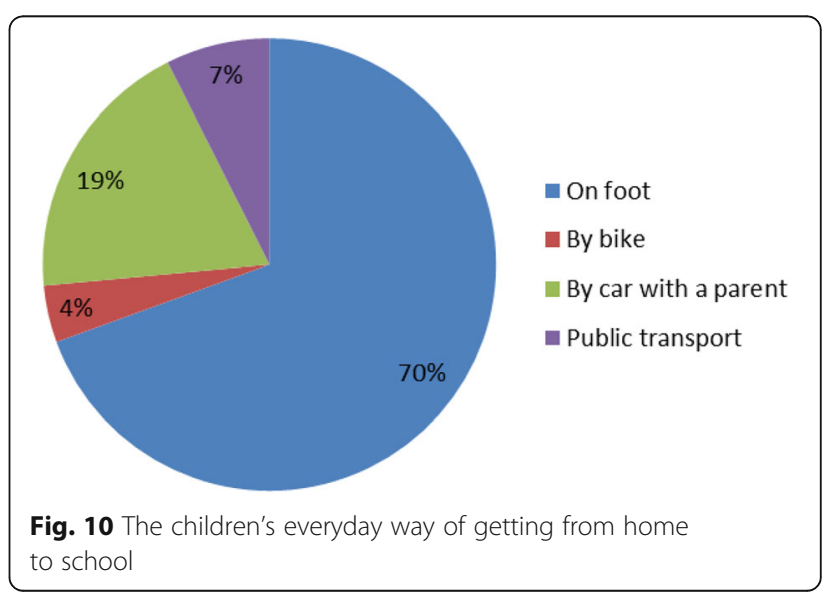




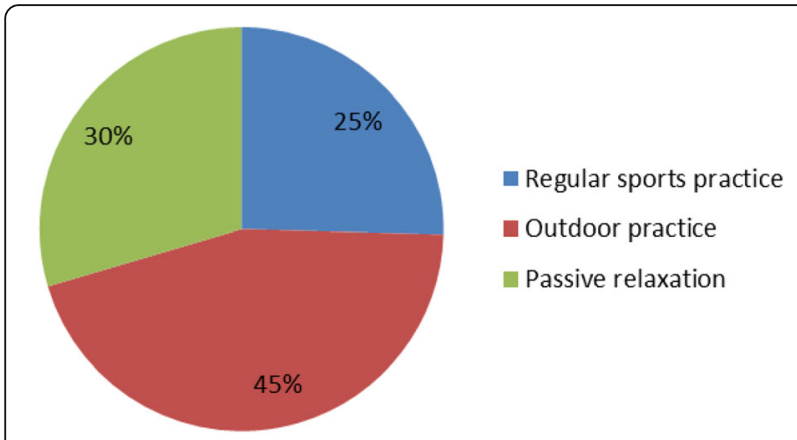

Fig 11. The way of spending free time by children.

The subsequent analysis was to verify if a number of snacks consumed by a child during the day and the use of fast-food bars by a child significantly correlates with the BMI level. For this purpose, the analysis of the correlation with the application of Spearman's rho coefficient was conducted again. The calculations were carried out separately in a group of girls and separately in a group of boys divided by four age categories. In accordance with the results listed in Table 9. Among girls, only one statistically significant correlation between BMI and a number of snacks consumed by a child during the day was observed. This correlation occurred among 12-yearold girls, its direction is negative and the correlation is negative. We may conclude that the fewer snacks are consumed during the day in this age group, the higher the BMI level is. In a group of boys, however, the statistically significant correlation between BMI and the frequency of the use of fast-food bars by a child was observed. This correlation is observed among 13-yearlold boys. The correlation is moderate, and its direction is positive, which means that the more frequently 13year-old boys use fast-food bars, the higher their BMI level is.

The analysis comprised as well the issue related to the fact which products were the most frequently bought by children in school shops. For this purpose, the analysis

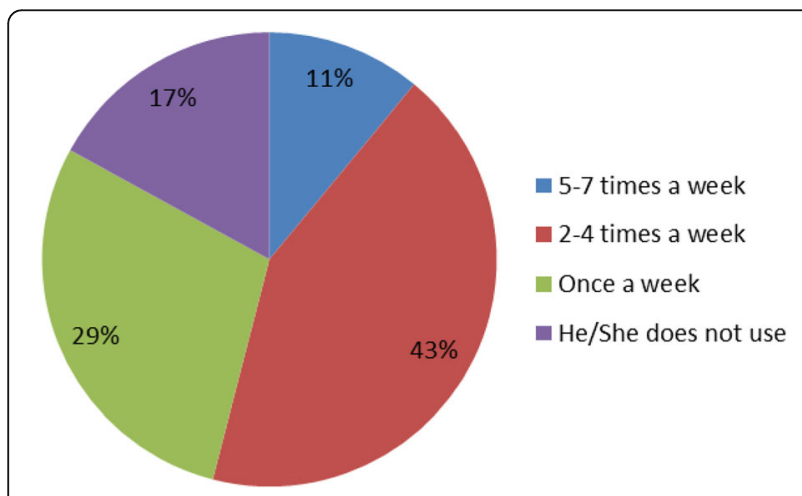

Fig. 12 The frequency of the use of sports facilities by children

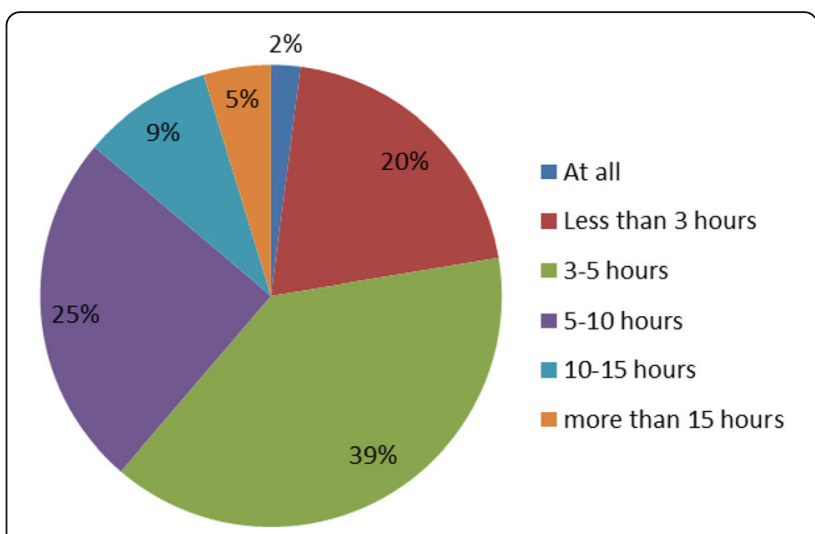

Fig. 13 Average time within the week period dedicated to physical activity in the analysed group of children

of the frequency in the groups isolated in terms of sex, age, and the BMI level (underweight, normal weight, overweight, obesity). It is observed that in a group of girls the highest percentage of children either buys something sweet or they do not buy anything in a school shop (Table 10).

In a group of boys, salty snacks or sweet products were the most frequently selected products. A considerable percentage of boys in each isolated subgroup does not buy anything in a school shop. The results were presented in Table 11.

Apart from the correlation between dietary habits and BMI, it was also verified if there is the correlation between body mass index and the children's physical activity. The calculations were carried out by means of the analysis of the correlation with Spearman's rho coefficient. The obtained results demonstrate that in a group of the youngest girls (10-year-old ones) and 11- and 12year-old boys, there is a significant correlation between BMI and a number of hours a week spent by a child on physical activity This correlation is weak (in a group of 10-year-old girls and 12-year-old boys) and the moderate one (in a group of 11-year-old boys), and its direction is negative. It means that the more hours a child spends on physical activity, the lower its BMI level is. This correlation did not occur in the remaining age groups. The frequency (per week) of the use of sports facilities by a child did not correlate with BMI. The results of the analysis are juxtaposed in Table 12.

In the table below (Table 13), the way of spending free time in a group of girls was juxtaposed depending on age and the BMI level (underweight, normal weight, overweight, obesity). The highest percentage of girls was actively spending their free time. However, passive relaxation is the most frequent form of spending free time among 12-year-old children with overweight and obesity. Due to a small number of children in particular subgroups (children with underweight, overweight and 
Table 6 Average results, standard deviations and significance of differences in relations to body mass index depending on the frequency of the use of sports facilities

\begin{tabular}{|c|c|c|c|c|c|c|c|c|c|c|c|}
\hline & $5-7$ ti & ek $(n=62)$ & $2-4 \mathrm{ti}$ & k $(n=247)$ & Once & $(n=173)$ & At all & = 89) & $H$ & $p$ & $E^{2}$ \\
\hline & $M$ & $S D$ & $M$ & $S D$ & $M$ & $S D$ & $M$ & $S D$ & & & \\
\hline $\mathrm{BMI}$ & 17.60 & 2.81 & 18.07 & 3.63 & 18.47 & 3.36 & 18.95 & 3.76 & 7.23 & 0.065 & 0.01 \\
\hline
\end{tabular}

obesity), we cannot fully conclude statistically the ways of spending free time depending on the BMI level.

It is observed, in a group of 11-, 12- and 13-year-old boys, that children with obesity prefer passive relation as a form of spending their free time (Table 14). Also, boys aged 12 with overweight are not physically active in their free time. Diverse forms of spending free time are observed in a group of people with normal weight. Similarly, as in a group of girls, also in a group of boys due to a small number of children in particular subgroups (children with underweight, overweight and obesity), we cannot fully conclude statistically the ways of spending free time depending on the BMI level.

Table 7 The correlation between BMI and the frequency of meal consumption depending on age and sex

\section{Body mass index (BMI)}

Girls

$\begin{array}{llll}10 \text { years } & 11 \text { years } & 12 \text { years } & 13 \text { years } \\ \text { old } & \text { old } & \text { old } & \text { old } \\ (n=90) & (n=71) & (n=65) & (n=32)\end{array}$

The frequency of meal consumption

\begin{tabular}{|c|c|c|c|c|c|}
\hline \multirow[t]{2}{*}{ Breakfast } & Spearman's rho & -0.03 & 0.14 & -0.10 & -0.36 \\
\hline & significance & 0.776 & 0.221 & 0.389 & 0.038 \\
\hline \multirow[t]{2}{*}{ Packed lunch } & Spearman's rho & -0.19 & 0.14 & -0.17 & -0.22 \\
\hline & significance & 0.060 & 0.218 & 0.160 & 0.235 \\
\hline \multirow[t]{2}{*}{ Dinner } & Spearman's rho & -0.06 & 0.19 & - & - \\
\hline & significance & 0.527 & 0.092 & - & - \\
\hline \multirow[t]{2}{*}{ Supper } & Spearman's rho & 0.08 & 0.12 & -0.07 & -0.06 \\
\hline & significance & 0.422 & 0.277 & 0.585 & 0.729 \\
\hline \multicolumn{6}{|l|}{ Boys } \\
\hline & & $\begin{array}{l}10 \text { years } \\
\text { old } \\
(n=96)\end{array}$ & $\begin{array}{l}11 \text { years } \\
\text { old } \\
(n=51)\end{array}$ & $\begin{array}{l}12 \text { years } \\
\text { old } \\
(n=65)\end{array}$ & $\begin{array}{l}13 \text { years } \\
\text { old } \\
(n=32)\end{array}$ \\
\hline \multicolumn{6}{|c|}{ The frequency of meal consumption } \\
\hline \multirow[t]{2}{*}{ Breakfast } & Spearman's rho & -0.03 & 0.16 & 0.26 & 0.11 \\
\hline & significance & 0.748 & 0.256 & 0.025 & 0.539 \\
\hline \multirow[t]{2}{*}{ Packed lunch } & Spearman's rho & -0.08 & 0.15 & -0.12 & -0.29 \\
\hline & significance & 0.427 & 0.286 & 0.334 & 0.101 \\
\hline \multirow[t]{2}{*}{ Dinner } & Spearman's rho & 0.09 & - & -0.01 & - \\
\hline & significance & 0.327 & - & 0.910 & - \\
\hline \multirow[t]{2}{*}{ Supper } & Spearman's rho & 0.04 & -0.08 & 0.16 & 0.09 \\
\hline & significance & 0.664 & 0.564 & 0.171 & 0.604 \\
\hline
\end{tabular}

Finally, it was analysed if the participation in free, additional, extracurricular physical activities is correlated with the BMI level (underweight, normal weight, overweight, obesity). The conducted $x^{2}$ tests demonstrate that both in a group of girls and in a group of boys the participation in free, additional extracurricular physical activities is not correlated with the BMI level. The obtained results are demonstrated in Table 15.

\section{Discussion}

The research results of other scholars related to children's dietary habits are inconclusive. Kołłajtis-Dołowy et al. [7] in their study pointed to the regularity of the consumption of main meals during the day by children aged 11-12 from Białystok. Breakfast and supper were consumed by $93 \%$ of interviewed children, and lunch by even $98 \%$ of adolescents. The similar results are also confirmed by other authors in their studies $[8,9]$. On the other hand, much lower percentages were obtained in many other scientific reports indicating that breakfast was consumed from approximately 60 to $80 \%$ of respondents, lunch from 70 to $85 \%$; however, suppers turned out to be the most rarely consumed main meal by children during the day (from approx. 50 to 78\%) [10-13]. What is important is that a definitely low percentage of children consume their packed lunch in schools. It turns out that only slightly half of analysed children consume it every day. This is a worrying phenomenon, as other authors emphasise as well $[9,11,13-16]$. Ramotowska et al. analysing children aged 12-17 indicated that breakfast was omitted in the youth group by $13.5 \%$ of children. What is more, approximately $3 \%$ of interviewees did not consume either breakfast or their packed lunch [17]. The studies related to school youth conducted in the years 2002-2006, point to a negative tendency concerning the consumption of breakfasts. Namely, the frequency of eating breakfasts on school days decreases with age. There is also a considerable difference in the frequency of consumption of a morning meal between girls and boys, to the disadvantage of girls. Dzielska et al. noticed that in 2006 (compared to 2002) the frequency of a daily consumption of breakfast decreased. It concerned both girls and boys. It was noted as well that 15-year-old girls eat breakfasts much more rarely than boys. In the group of 11-year-olds, the percentage of learners consuming breakfast amounted to 
Table 8 The correlation between the frequency of the consumption of the specific food products depending on age and sex Body mass index (BMI)

Girls

10 years old $(n=90) \quad 11$ years old $(n=71) \quad 12$ years old $(n=65) \quad 13$ years old $(n=32)$

The consumption frequency of products:

\begin{tabular}{|c|c|c|c|c|c|}
\hline \multirow[t]{2}{*}{ Milk } & Spearman's rho & 0.11 & 0.17 & -0.05 & 0.12 \\
\hline & significance & 0.278 & 0.126 & 0.684 & 0.515 \\
\hline \multirow[t]{2}{*}{ Water } & Spearman's rho & -0.04 & 0.12 & -0.05 & -0.18 \\
\hline & significance & 0.734 & 0.301 & 0.662 & 0.308 \\
\hline \multirow[t]{2}{*}{ Sweet drinks } & Spearman's rho & -0.03 & -0.18 & 0.18 & 0.42 \\
\hline & significance & 0.756 & 0.119 & 0.141 & 0.021 \\
\hline \multirow[t]{2}{*}{ Fish } & Spearman's rho & 0.01 & 0.13 & -0.16 & 0.14 \\
\hline & significance & 0.969 & 0.273 & 0.190 & 0.446 \\
\hline \multirow[t]{2}{*}{ Brown bread } & Spearman's rho & -0.28 & -0.20 & -0.23 & -0.23 \\
\hline & significance & 0.008 & 0.086 & 0.062 & 0.208 \\
\hline \multirow[t]{2}{*}{ Meat } & Spearman's rho & -0.25 & 0.12 & 0.15 & 0.40 \\
\hline & significance & 0.013 & 0.294 & 0.221 & 0.024 \\
\hline \multirow[t]{2}{*}{ Salty snacks/sweets } & Spearman's rho & -0.01 & 0.02 & 0.07 & 0.13 \\
\hline & significance & 0.900 & 0.848 & 0.574 & 0.469 \\
\hline \multirow[t]{2}{*}{ Fruit/vegetables } & Spearman's rho & 0,13 & 0,02 & $-0,18$ & 0,14 \\
\hline & significance & 0,197 & 0,833 & 0,135 & 0,418 \\
\hline \multicolumn{6}{|l|}{ Boys } \\
\hline & & 10 years old $(n=96)$ & 11 years old $(n=51)$ & 12 years old $(n=65)$ & 13 years old $(n=32)$ \\
\hline \multicolumn{6}{|c|}{ The consumption frequency of products: } \\
\hline \multirow[t]{2}{*}{ Milk } & Spearman's rho & 0.18 & 0.27 & 0.12 & 0.14 \\
\hline & significance & 0.068 & 0.044 & 0.309 & 0.426 \\
\hline \multirow[t]{2}{*}{ Water } & Spearman's rho & 0.01 & -0.11 & -0.31 & 0.23 \\
\hline & significance & 0.941 & 0.424 & 0.009 & 0.203 \\
\hline \multirow[t]{2}{*}{ Sweet drinks } & Spearman's rho & 0.18 & -0.07 & 0.07 & 0.15 \\
\hline & significance & 0.081 & 0.601 & 0.562 & 0.383 \\
\hline \multirow[t]{2}{*}{ Fish } & Spearman's rho & -0.05 & 0.11 & 0.07 & -0.02 \\
\hline & significance & 0.599 & 0.443 & 0.592 & 0.931 \\
\hline \multirow[t]{2}{*}{ Brown bread } & Spearman's rho & -0.05 & 0.00 & -0.21 & -0.33 \\
\hline & significance & 0.660 & 0.973 & 0.083 & 0.062 \\
\hline \multirow[t]{2}{*}{ Meat } & Spearman's rho & -0.01 & 0.09 & 0.15 & -0.14 \\
\hline & significance & 0.960 & 0.530 & 0.228 & 0.415 \\
\hline \multirow[t]{2}{*}{ Salty snacks/sweets } & Spearman's rho & -0.03 & -0.15 & 0.08 & 0.03 \\
\hline & significance & 0.743 & 0.278 & 0.514 & 0.847 \\
\hline \multirow[t]{2}{*}{ Fruit/vegetables } & Spearman's rho & 0.20 & 0.19 & 0.05 & -0.10 \\
\hline & significance & 0.044 & 0.165 & 0.704 & 0.583 \\
\hline
\end{tabular}

$71-73 \%$; these values were similar between two sexes [18]. On the other hand, Stankiewicz et al. asked the interviewed children aged 6-18 about consuming breakfast before going to school. The results were interesting: $73 \%$ of analysed learners answered that they always eat breakfast, $16 \%$ claimed that they sometimes eat breakfast; however, approx. $10 \%$ of respondents marked the answer "never" or "almost never" [19]. The results of our studies conducted in 2016 among children aged 613 were even worse, in which we demonstrated that $64.39 \%$ of learners eat breakfast before leaving home. However, it was noted as well that $10.98 \%$ do not 
Table 9 The correlation between a number of snacks consumed by a child during the day and the frequency of the use of fastfood bars and BMI depending on age and sex

\begin{tabular}{|c|c|c|c|c|c|}
\hline \multicolumn{6}{|l|}{ Girls } \\
\hline & & 10 years old $(n=89)$ & 11 years old $(n=76)$ & 12 years old $(n=66)$ & 13 years old $(n=30)$ \\
\hline \multirow[t]{2}{*}{ A number of snacks consumed by a child during the day } & Spearman's rho & -0.03 & 0.01 & -0.36 & -0.15 \\
\hline & significance & 0.790 & 0.997 & 0.003 & 0.452 \\
\hline \multirow[t]{2}{*}{ The frequency of the use of fast-food bars by a child } & Spearman's rho & -0.14 & 0.07 & 0.06 & 0.12 \\
\hline & significance & 0.178 & 0.529 & 0.633 & 0.505 \\
\hline \multicolumn{6}{|l|}{ Boys } \\
\hline & & 10 years old $(n=101)$ & 11 years old $(n=49)$ & 12 years old $(n=71)$ & 13 years old $(n=34)$ \\
\hline \multirow[t]{2}{*}{ A number of snacks consumed by a child during the day } & Spearman's rho & -0.13 & 0.17 & -0.06 & -0.14 \\
\hline & significance & 0.185 & 0.241 & 0.630 & 0.433 \\
\hline \multirow[t]{2}{*}{ The frequency of the use of fast-food bars by a child } & Spearman's rho & 0.13 & 0.12 & -0.14 & 0.40 \\
\hline & significance & 0.190 & 0.378 & 0.224 & 0.016 \\
\hline
\end{tabular}

Table 10 The products bought in a school shop in a group of girls depending on age and BMl level (underweight, normal weight, overweight, obesity)

\begin{tabular}{|c|c|c|c|c|c|c|c|c|c|}
\hline & & \multicolumn{2}{|c|}{ Underweight } & \multicolumn{2}{|c|}{ Normal weight } & \multicolumn{2}{|c|}{ Overweight } & \multicolumn{2}{|c|}{ Obesity } \\
\hline & & $n$ & $\%$ & $n$ & $\%$ & $n$ & $\%$ & $n$ & $\%$ \\
\hline \multirow[t]{7}{*}{10 years old } & Something sweet & 7 & 50.0 & 17 & 26.15 & 5 & 31.25 & 6 & 20.0 \\
\hline & Salty snacks & 3 & 21.43 & 9 & 13.85 & 0 & 0.0 & 0 & 0.0 \\
\hline & Doesn't buy & 4 & 28.57 & 26 & 40.0 & 9 & 56.25 & 24 & 80.0 \\
\hline & Sweet drinks & 0 & 0.0 & 1 & 1.54 & 0 & 0.0 & 0 & 0.0 \\
\hline & Mineral water & 0 & 0.0 & 5 & 7.69 & 0 & 0.0 & 0 & 0.0 \\
\hline & Fruit/vegetables & 0 & 0.0 & 2 & 3.08 & 0 & 0.0 & 0 & 0.0 \\
\hline & Something else & 0 & 0.0 & 5 & 7.69 & 2 & 12.5 & 0 & 0.0 \\
\hline \multirow[t]{7}{*}{11 years old } & Something sweet & 2 & 16.7 & 3 & 11.54 & 1 & 6.25 & 0 & 0.0 \\
\hline & Doesn't buy & 6 & 50.0 & 14 & 53.85 & 7 & 43.75 & 10 & 47.62 \\
\hline & Salty snacks & 0 & 0.0 & 2 & 7.69 & 0 & 0.0 & 11 & 52.38 \\
\hline & Sweet drinks & 0 & 0.0 & 0 & 0.0 & 0 & 0.0 & 0 & 0.0 \\
\hline & Mineral water & 0 & 0.0 & 6 & 23.08 & 6 & 37.5 & 0 & 0.0 \\
\hline & Fruit/vegetables & 0 & 0.0 & 0 & 0.0 & 0 & 0.0 & 0 & 0.0 \\
\hline & Something else & 4 & 33.3 & 1 & 6.25 & 2 & 12.5 & 0 & 0.0 \\
\hline \multirow[t]{7}{*}{12 years old } & Something sweet & 0 & 0.0 & 5 & 21.74 & 0 & 0.0 & 10 & 58.83 \\
\hline & Salty snacks & 0 & 0.0 & 2 & 8.7 & 0 & 0.0 & 0 & 0.0 \\
\hline & Sweet drinks & 0 & 0.0 & 0 & 0.0 & 7 & 50.0 & 0 & 0.0 \\
\hline & Mineral water & 0 & 0.0 & 1 & 4.35 & 0 & 0.0 & 0 & 0.0 \\
\hline & Fruit/vegetables & 0 & 0.0 & 0 & 0.0 & 0 & 0.0 & 0 & 0.0 \\
\hline & Doesn't buy & 22 & 100.0 & 12 & 52.17 & 7 & 50.0 & 0 & 0.0 \\
\hline & Something else & 0 & 0.0 & 3 & 13.04 & 0 & 0.0 & 7 & 41.17 \\
\hline \multirow[t]{4}{*}{13 years old } & Something sweet & 0 & 0.0 & 2 & 18.18 & 0 & 0.0 & 2 & 25.0 \\
\hline & Salty snacks & 0 & 0.0 & 0 & 0 & 1 & 20.0 & 2 & 25.0 \\
\hline & Mineral water & 0 & 0.0 & 3 & 27.27 & 1 & 20.0 & 2 & 25.0 \\
\hline & Doesn't buy & 12 & 100.0 & 6 & 54.55 & 3 & 60.0 & 2 & 25.0 \\
\hline
\end{tabular}


Table 11 The products bought in a school shop in a group of boys depending on age and BMI level (underweight, normal weight, overweight, obesity)

\begin{tabular}{|c|c|c|c|c|c|c|c|c|c|}
\hline & & \multicolumn{2}{|c|}{ Underweight } & \multicolumn{2}{|c|}{ Normal weight } & \multicolumn{2}{|c|}{ Overweight } & \multicolumn{2}{|c|}{ Obesity } \\
\hline & & $n$ & $\%$ & $n$ & $\%$ & $n$ & $\%$ & $n$ & $\%$ \\
\hline \multirow[t]{7}{*}{10 years old } & Something sweet & 2 & 16.67 & 7 & 14 & 4 & 25 & 0 & 0.0 \\
\hline & Doesn't buy & 10 & 83.33 & 30 & 60 & 6 & 37.5 & 20 & 68.97 \\
\hline & Salty snacks & 0 & 0.0 & 7 & 14 & 0 & 0.0 & 9 & 31.03 \\
\hline & Sweet drinks & 0 & 0.0 & 1 & 2 & 2 & 12.5 & 0 & 0.0 \\
\hline & Mineral water & 0 & 0.0 & 3 & 6 & 0 & 0.0 & 0 & 0.0 \\
\hline & Fruit/vegetables & 0 & 0.0 & 0 & 0 & 0 & 0.0 & 0 & 0.0 \\
\hline & Something else & 0 & 0.0 & 2 & 4 & 4 & 25 & 0 & 0.0 \\
\hline \multirow[t]{6}{*}{11 years old } & Something sweet & 0 & 0.0 & 4 & 20 & 4 & 28.57 & 10 & 50 \\
\hline & Salty snacks & 6 & 54.55 & 2 & 10 & 0 & 0.0 & 10 & 50 \\
\hline & Sweet drinks & 0 & 0.0 & 1 & 5 & 0 & 0.0 & 0 & 0.0 \\
\hline & Mineral water & 0 & 0.0 & 2 & 10 & 0 & 0.0 & 0 & 0.0 \\
\hline & Doesn't buy & 3 & 27.27 & 10 & 50 & 10 & 71.43 & 0 & 0.0 \\
\hline & Something else & 2 & 18.18 & 1 & 5 & 0 & 0.0 & 0 & 0.0 \\
\hline \multirow[t]{7}{*}{12 years old } & Doesn't buy & 20 & 100.0 & 7 & 35 & 2 & 20 & 0 & 0.0 \\
\hline & Something sweet & 0 & 0.0 & 5 & 25 & 0 & 0.0 & 15 & 75 \\
\hline & Salty snacks & 0 & 0.0 & 4 & 20 & 3 & 30 & 5 & 25 \\
\hline & Sweet drinks & 0 & 0.0 & 2 & 10 & 0 & 0.0 & 0 & 0.0 \\
\hline & Mineral water & 0 & 0.0 & 2 & 10 & 3 & 30 & 0 & 0.0 \\
\hline & Fruit/vegetables & 0 & 0.0 & 0 & 0.0 & 1 & 10 & 0 & 0.0 \\
\hline & Something else & 0 & 0.0 & 0 & 0.0 & 1 & 10 & 0 & 0.0 \\
\hline \multirow[t]{7}{*}{13 years old } & Doesn't buy & 10 & 100.0 & 4 & 40 & 0 & 0.0 & 0 & 0.0 \\
\hline & Something sweet & 0 & 0.0 & 2 & 20 & 3 & 60 & 5 & 50 \\
\hline & Salty snacks & 0 & 0.0 & 2 & 20 & 1 & 20 & 5 & 50 \\
\hline & Sweet drinks & 0 & 0.0 & 1 & 10 & 0 & 0.0 & 0 & 0.0 \\
\hline & Mineral water & 0 & 0.0 & 1 & 10 & 1 & 20 & 0 & 0.0 \\
\hline & Fruit/vegetables & 0 & 0.0 & 0 & 0.0 & 0 & 0.0 & 0 & 0.0 \\
\hline & Something else & 0 & 0.0 & 0 & 0.0 & 0 & 0.0 & 0 & 0.0 \\
\hline
\end{tabular}

practise that. Supper and lunch (respectively: 93.90\%, 80.49\%) [2] were the most often consumed meals during the day in the analysed group. However, Jodkowska et al. indicated that almost half of the interviewed teenagers eat breakfast; however, the percentage of girls, who never eat their first meal, increases with age. It was noted as well that obese youth omits main meals considerably more frequently compared to the control group. In case of super, both obese girls $(20 \%)$ and obese boys $(10 \%)$ omitted this meal considerably more frequently than girls $(6 \%)$ and boys (4\%) with a normal body weight [20]. Gajewska and Zawieska in their study compared children's and parents' answers. They indicated that in accordance with the opinions of both children and parents, daily breakfast was consumed by approximately 93\% of the analysed learners. The discrepancies occurred with reference to lunch. All interviewed parents claimed that their children consume lunch every day (100\%); however, only $90.3 \%$ of the analysed learners declared a daily consumption of lunch. Similarly, a daily consumption of supper by children occurred significantly more often in the parents' opinions than in the children's opinions (respectively, $95.4 \%$ vs. $78.5 \%$ ) [21].

Kołłajtis et al. noticed in their study that girls much more often reached for milk with different additives: with oatmeal, with cornflakes, pasta $(p>0.04)$. Moreover, they indicated that milk and milk beverages were drunk everyday by only $64 \%$ of children [7]. SosnowskaBielicz and Wrótniak pointed out that $66 \%$ of children drink from 1 to $2 \mathrm{~L}$ of liquids every day, whereas children most willingly reach for fruit juices, much more rarely for water or tea [22]. What is interesting, Harnack et al. proved that the low consumption of milk may be related to the higher consumption of sweet sparkling 
Table 12 The correlation between BMI and a number of hours spent by a child on physical activity and the frequency (a week) of the use of sports facilities by a child depending on age and sex

\begin{tabular}{|c|c|c|c|c|c|}
\hline \multicolumn{6}{|l|}{ Girls } \\
\hline & & $\begin{array}{l}10 \text { years old } \\
(n=94)\end{array}$ & $\begin{array}{l}11 \text { years old } \\
(n=76)\end{array}$ & $\begin{array}{l}12 \text { years old } \\
(n=69)\end{array}$ & $\begin{array}{l}13 \text { years old } \\
(n=32)\end{array}$ \\
\hline \multirow[t]{2}{*}{ Number of hours a week spent by a child on physical activity } & Spearman's rho & -0.28 & -0.15 & 0.05 & -0.11 \\
\hline & significance & 0.006 & 0.193 & 0.691 & 0.548 \\
\hline \multirow[t]{2}{*}{ The frequency (a week) of the use of sports facilities by a child } & Spearman's rho & 0.19 & 0.09 & -0.03 & 0.11 \\
\hline & significance & 0.061 & 0.413 & 0.797 & 0.563 \\
\hline \multicolumn{6}{|l|}{ Boys } \\
\hline & & $\begin{array}{l}10 \text { years old } \\
(n=108)\end{array}$ & $\begin{array}{l}11 \text { years old } \\
(n=54)\end{array}$ & $\begin{array}{l}12 \text { years old } \\
(n=75)\end{array}$ & $\begin{array}{l}13 \text { years old } \\
(n=34)\end{array}$ \\
\hline \multirow[t]{2}{*}{ Number of hours a week spent by a child on physical activity } & Spearman's rho & -0.11 & -0.40 & -0.26 & -0.05 \\
\hline & significance & 0.249 & 0.003 & 0.025 & 0.768 \\
\hline \multirow[t]{2}{*}{ The frequency (a week) of the use of sports facilities by a child } & Spearman's rho & 0.05 & 0.25 & 0.10 & 0.23 \\
\hline & significance & 0.624 & 0.071 & 0.392 & 0.188 \\
\hline
\end{tabular}

beverages [23]. Woynarowska and Mazur presented the data, which demonstrate that $41 \%$ of youth do not consume milk every day [24]. On the other hand, in the study by Marcinkowska et al., 44\% of learned admitted to a regular consumption of sweet sparkling beverages, whereas in this group, boys (56\%) prevail over girls (44\%). Sixteen percent of respondents claimed that this kind of liquid constitutes a basic beverage in their daily diet. Moreover, almost all junior high students and high school students declared that they drink mineral water$96 \%$, where the majority, that is as many as $68 \%$, drink still mineral water. The vast majority admits that they regularly consume fruit juices-94\%. Ten percent among the interviewed youth do not drink milk, $12 \%$ drink one glass a week and two glasses a week are drunk by $13 \%$. Polish youth drink on average 4.8 glasses of milk a week. It was observed as well that boys more often reach for milk than girls [25]. Similarly, it was indicated in our previous study that only $53.15 \%$ of learners $(49.61 \%$ of girls and $56.75 \%$ of boys) in the analysed group consume milk and its products every day, and almost every third boy and over $45 \%$ of girls consume these food products several times a week. Moreover, it was proved that mineral water is drunk everyday by $62.20 \%$ of respondents (63.28\% of girls and $61.11 \%$ of boys) [26]. However, in the research conducted in Australia by Jensen et al., it was proved that the consumption of sweet drinks is declared by as many as $77 \%$ of children and youth. Average

Table 13 The way of spending free time in a group of girls depending on age and BMI level (underweight, normal weight, overweight, obesity)

\begin{tabular}{|c|c|c|c|c|c|c|c|c|c|}
\hline & & \multicolumn{2}{|c|}{ Underweight } & \multicolumn{2}{|c|}{ Normal weight } & \multicolumn{2}{|c|}{ Overweight } & \multicolumn{2}{|c|}{ Obesity } \\
\hline & & $n$ & $\%$ & $n$ & $\%$ & $n$ & $\%$ & $n$ & $\%$ \\
\hline \multirow[t]{3}{*}{10 years old } & Regular sports practice & 4 & 28.6 & 20 & 30.77 & 5 & 31.25 & 10 & 33.3 \\
\hline & Outdoor activities & 8 & 57.1 & 40 & 61.54 & 5 & 31.25 & 10 & 33.3 \\
\hline & Passive relaxation & 2 & 14.3 & 5 & 7.69 & 6 & 37.5 & 10 & 33.3 \\
\hline \multirow[t]{3}{*}{11 years old } & Regular sports practice & 6 & 50.0 & 5 & 19.23 & 2 & 12.5 & 10 & 47.62 \\
\hline & Outdoor activities & 6 & 50.0 & 14 & 53.85 & 7 & 43.75 & 10 & 47.62 \\
\hline & Passive relaxation & 0 & 0.0 & 7 & 26.92 & 7 & 43.75 & 1 & 4.76 \\
\hline \multirow[t]{3}{*}{12 years old } & Regular sports practice & 0 & 0.0 & 6 & 26.09 & 0 & 0.0 & 0 & 0.0 \\
\hline & Outdoor activities & 14 & 63.63 & 12 & 52.17 & 0 & 0.0 & 0 & 0.0 \\
\hline & Passive relaxation & 8 & 36.36 & 5 & 21.74 & 14 & 100.0 & 17 & 100.0 \\
\hline \multirow[t]{3}{*}{13 years old } & Regular sports practice & 0 & 0.0 & 3 & 27.28 & 2 & 40.0 & 1 & 12.5 \\
\hline & Outdoor activities & 12 & 100.0 & 3 & 27.27 & 3 & 60.0 & 3 & 37.5 \\
\hline & Passive relaxation & 0 & 0.0 & 5 & 45.45 & 0 & 0.0 & 4 & 50.0 \\
\hline
\end{tabular}


Table 14 The way of spending free time in a group of boys depending on age and BMI level (underweight, normal weight, overweight, obesity)

\begin{tabular}{|c|c|c|c|c|c|c|c|c|c|}
\hline & & \multicolumn{2}{|c|}{ Underweight } & \multicolumn{2}{|c|}{ Normal weight } & \multicolumn{2}{|c|}{ Overweight } & \multicolumn{2}{|c|}{ Obesity } \\
\hline & & $n$ & $\%$ & $n$ & $\%$ & $n$ & $\%$ & $n$ & $\%$ \\
\hline \multirow[t]{3}{*}{10 years old } & Regular sports practice & 0 & 0,0 & 20 & 40.0 & 2 & 12.5 & 12 & 40.0 \\
\hline & Outdoor activities & 6 & 50,0 & 25 & 50.0 & 6 & 37.5 & 12 & 40.0 \\
\hline & Passive relaxation & 6 & 50,0 & 5 & 10.0 & 8 & 50.0 & 6 & 20.0 \\
\hline \multirow[t]{3}{*}{11 years old } & Regular sports practice & 2 & 18.18 & 5 & 25.0 & 0 & 0.0 & 0 & 0.0 \\
\hline & Outdoor activities & 7 & 63.64 & 9 & 45.0 & 3 & 21.43 & 2 & 10.0 \\
\hline & Passive relaxation & 2 & 18.18 & 6 & 30.0 & 11 & 78.57 & 18 & 90.0 \\
\hline \multirow[t]{3}{*}{12 years old } & Regular sports practice & 0 & 0.0 & 3 & 15.0 & 2 & 20.0 & 0 & 0.0 \\
\hline & Outdoor activities & 10 & 50.0 & 10 & 50,0 & 5 & 50.0 & 2 & 10.0 \\
\hline & Passive relaxation & 10 & 50.0 & 7 & 35,0 & 3 & 30.0 & 18 & 90.0 \\
\hline \multirow[t]{3}{*}{13 years old } & Regular sports practice & 5 & 50.0 & 5 & 50,0 & 0 & 0.0 & 1 & 10.0 \\
\hline & Outdoor activities & 5 & 50.0 & 2 & 20,0 & 2 & 40.0 & 2 & 20.0 \\
\hline & Passive relaxation & 0 & 0.0 & 3 & 30,0 & 3 & 60.0 & 7 & 70.0 \\
\hline
\end{tabular}

consumption amounted to $500 \mathrm{ml}$, and almost $31 \%$ of respondents consumed over $750 \mathrm{ml}$ a day [27]. It is interesting because in accordance with the American Academy of Pediatrics, the consumption of sweet drinks during the last 20 years increased to $300 \%$, which caused displacement of milk consumption [28].

The results obtained by Kołłajtis-Dołowy et al. seem worrying as well [7], concerning the quantity of fish and brown bread consumed by children. It turned out that only about $30 \%$ of learners declared fish consumption once a week and this is the lower percentage from the one obtained by Fraczek in her study [11]. The opposite results concerned brown bread consumption in both interviewed groups. Namely, owing to Frączek [11], over half of learners were consuming brown bread at least once a day. The lower percentages related to the consumption of this food product were described by Kołłajtis-Dołowy et al. [7]. Stefańska et al., marking the frequency of brown bread consumption, proved that $40 \%$ of interviewed children consume it more rarely than 2-3 times a week, whereas younger boys significantly more often consumed this kind of bread than older boys [29]. These results do not significantly diverge from the reports by Cieślik et al. [30] and from other studies by Szczepańska et al. [31], in which too low brown bread consumption is observed. Meat consumption was analysed in these studies as well. It was indicated that in all analysed groups of children, only the small percentage of learners consume meat more rarely than 2-3 times a week. Almost $40 \%$ of all girls and $50 \%$ of boys consume meat and its products several times a day [31]. PieszkoKlejnowska et al. proved that $60 \%$ of learners consumed meat every day, 30\%-2-3 times a week, and about $4 \%$ did not eat these products at all [32]. Stefańska et al., evaluating fish consumption in their studies, indicated that $70 \%$ of children and youth, regardless of sex, consumed them 2-3 times a week [31]. However, Zychowicz-Jeżewska et al. indicated that over half of interviewed learners pointed to fish consumption only occasionally, and every tenth person did not consume them at all [33]. Similar results were obtained by Goluch-Koniuszy, proving that fish consumption is low regardless of age and sex of the interviewed children in the city of Szczecin [34].

Kobus et al. indicated that the vast majority, that is as many as $82.1 \%$ of interviewed children, occasionally consumed fast-food meals. Among the analysed children, $17.4 \%$ ate them 1-3 times a week, whereas most of them was constituted by boys (29.5\% of boys and only $9.8 \%$ of girls). One person admitted to the consumption of fastfood meals every day and it was a boy. Statistically significant differences between boys and girls in terms of the frequency of the consumption of this kind of meals $(p=0.0002)$ [35] was observed as well. The results of the study by Komosińska et al. are frightening, which demonstrate that as many as $1 / 3$ of the analysed children consume fast-food dishes every day [36]. The results of the project (Childhood Obesity Surveillance Initiative) conducted in Poland in the years 2015-2017 demonstrate that nearly $3 / 4$ of 8 -year-olds consume salty snacks and fast-food products more rarely than once a week, whereas significantly more rarely these are girls than boys [37]. The studies by Gajewska et al. turned out to be remarkably interesting, comparing parents' knowledge related to the consumption of specific food products by their children in relation to the declarations made by the very children. As it turned out, owing to parents, over half of children $(53.5 \%)$ consumed fast- 
Table 15 The participation in free additional extracurricular physical activities depending on BMI level (underweight, normal weight, overweight, obesity) divided by age and sex

\begin{tabular}{|c|c|c|c|c|c|c|c|c|c|}
\hline & & \multicolumn{8}{|c|}{ The participation in free additional extracurricular physical activities } \\
\hline & & \multicolumn{2}{|c|}{ Yes } & \multicolumn{2}{|c|}{ No } & \multirow[t]{2}{*}{$x^{2}$} & \multirow[t]{2}{*}{$p$} & \multirow[t]{2}{*}{$v_{c}$} & \multirow[t]{2}{*}{$p$} \\
\hline & & $\bar{n}$ & $\%$ & $\bar{n}$ & $\%$ & & & & \\
\hline \multicolumn{10}{|l|}{ Girls } \\
\hline \multirow[t]{4}{*}{10 years old } & Underweight & 7 & 50.0 & 7 & 50.0 & 2.34 & 0.505 & 0.16 & 0.505 \\
\hline & Normal weight & 25 & 38.4 & 40 & 61.6 & & & & \\
\hline & Overweight & 4 & 25.0 & 12 & 75.0 & & & & \\
\hline & Obesity & 5 & 16.7 & 25 & 83.3 & & & & \\
\hline \multirow[t]{4}{*}{11 years old } & Underweight & 7 & 58.33 & 5 & 41.67 & 4.21 & 0.240 & 0.23 & 0.240 \\
\hline & Normal weight & 10 & 38.46 & 16 & 61.54 & & & & \\
\hline & Overweight & 3 & 18.75 & 13 & 81.25 & & & & \\
\hline & Obesity & 0 & 0.0 & 21 & 100.0 & & & & \\
\hline \multirow[t]{4}{*}{12 years old } & Underweight & 11 & 50.0 & 11 & 50.0 & 3.65 & 0.302 & 0.23 & 0.302 \\
\hline & Normal weight & 5 & 21.74 & 18 & 78.26 & & & & \\
\hline & Overweight & 7 & 50.0 & 7 & 50.0 & & & & \\
\hline & Obesity & 8 & 47.06 & 9 & 52.94 & & & & \\
\hline \multirow[t]{4}{*}{13 years old } & Underweight & 6 & 50.0 & 6 & 50.0 & 1.53 & 0.676 & 0.22 & 0.676 \\
\hline & Normal weight & 2 & 18.19 & 9 & 81.81 & & & & \\
\hline & Overweight & 1 & 20.0 & 4 & 80.0 & & & & \\
\hline & Obesity & 2 & 25.0 & 6 & 75.0 & & & & \\
\hline \multicolumn{10}{|l|}{ Boys } \\
\hline \multirow[t]{4}{*}{10 years old } & Underweight & 7 & 58.33 & 5 & 41.67 & 5.02 & 0.170 & 0.22 & 0.170 \\
\hline & Normal weight & 18 & 27.69 & 47 & 72.31 & & & & \\
\hline & Overweight & 2 & 12.5 & 14 & 87.5 & & & & \\
\hline & Obesity & 7 & 23.33 & 23 & 76.67 & & & & \\
\hline \multirow[t]{4}{*}{11 years old } & Underweight & 0 & 0.00 & 11 & 100.0 & 6.18 & 0.103 & 0.34 & 0.103 \\
\hline & Normal weight & 3 & 15.0 & 17 & 85.0 & & & & \\
\hline & Overweight & 7 & 50.0 & 7 & 50.0 & & & & \\
\hline & Obesity & 0 & 0.0 & 20 & 100.0 & & & & \\
\hline \multirow[t]{4}{*}{12 years old } & Underweight & 0 & 0.0 & 20 & 100.0 & 1.63 & 0.653 & 0.15 & 0.653 \\
\hline & Normal weight & 4 & 20.0 & 16 & 80.0 & & & & \\
\hline & Overweight & 1 & 8.33 & 11 & 91.67 & & & & \\
\hline & Obesity & 0 & 0.0 & 20 & 100.0 & & & & \\
\hline \multirow[t]{4}{*}{13 years old } & Underweight & 10 & 100.0 & 0 & 0.0 & 0.36 & 0.301 & 0.33 & 0.301 \\
\hline & Normal weight & 3 & 30.0 & 7 & 70.0 & & & & \\
\hline & Overweight & 0 & 0.0 & 5 & 100.0 & & & & \\
\hline & Obesity & 0 & 0.0 & 10 & 100.0 & & & & \\
\hline
\end{tabular}

food products only occasionally or they did not eat them at all. However, in accordance with the learners' declarations, this result related to a significantly smaller group of children (33.3\%). Further, learners, characteristically more often than their parents claimed that they eat fastfood products $3-4$ times a week $(20.8 \%$ of children in the learners' opinion, $3.6 \%$ of children in the parents' opinion) [21]. On the other hand, French et al. in large studies comprising 4746 American learners aged 11-18 searched for the correlations between the consumption of unhealthy food in bars and the BMI of the analysed children. However, the significant correlations were not verified. What is interesting, body mass index in the group of boys eating in fast-food bars was even lower 
than in the group of boys eating in these bars more rarely-less than twice a week [38]. In 2014, Braithwaite et al. published the results of the questionnaire surveys conducted in 17 countries in the world (among others, from Poland, Japan, Thailand, Mexico, Portugal, Nigeria, Oman, South Korea), in which over 72,900 children aged 6-7 participated. It was demonstrated that only $22.6 \%$ of children declared frequent consumption of fast-food products, and $4.2 \%$ of them declare very frequent consumption. Frequent and very frequent consumption of this kind of food fluctuated from 10\% in Poland to 63\% in South Korea. What is interesting, a particularly high dissemination of fast-food consumption was observed in Latin America and Asian countries, similar ones to these in the USA and in the Western Europe. What is important, it was indicated as well, that the relation between fast-food consumption and higher BMI in children is maintained both among people from wealthy countries and these ones only developing [39].

As the research results indicate, low consumption of fruit and vegetables in the population of adolescents is worrying and common. In accordance with the research conducted in Białystok (Poland), only $72 \%$ of learners ate them every day, including below $42 \%$ of interviewees several times a day [7]. Stefańska et al. in their own studies indicated that raw fruit were consumed more often by girls in comparison to boys. She noted that fruit were consumed several times a day by $43 \%$ of girls and $38 \%$ of boys aged $10-12$ and $34 \%$ of girls and $27 \%$ of boys aged 13-15 [29]. On the other hand, Cieślik et al. in their research noticed that nearly $20 \%$ of the analysed learners do not consume fruit and vegetables [30]. The obtained results are also approximate to other studies [33]. The studies by Rasmussen et al. confirm that the frequency of raw fruit consumption decreased in the last two decades, regardless of sex [40]. McGuire [63] informed in their article that children and youth in the USA consume on average 1 portion of fruit and approx., 1.3 of portion of vegetables a day [41]. On the other hand, Weichselbaum and Buttriss [65] indicated that only 9\% of children from Great Britain aged 11-18 eat the recommended portion of fruit and vegetables a day [42].

Kołłajtis-Dołowy et al. demonstrated that $95 \%$ of children snacked between meals. What is incredibly interesting, fruit and vegetables were the most frequently snacked products. These products were declared by as many as $60 \%$ of interviewed children. Unfortunately, cakes and ice cream (over 40\%) and crisps and chips, up to $22 \%$, occurred among other products. Frequent consumption of sweets (including biscuits, crisps and chips) was observed in all children. Learners declared that they eat sweets more often than twice a day [7]. SosnowskaBielicz et al. received worrying data, which prove that as many as $70 \%$ of parents admit that their children snack between meal; what is worse, $65 \%$ of them report that sweets are these snacks [22]. The studies by Woynarowska and Mazur demonstrated that $40 \%$ of school youth consumed sweets at least once a day [24]. On the other hand, our previous studies prove that over $54 \%$ of learners consumed sweets and other salty snacks several times a week [26]. It turned out, in the studies conducted by Komosińska et al., that $48 \%$ of learners consume chocolate and sweets at least once a day, and every third interviewed person eats cakes and biscuits, whereas the frequency of the consumption of these products does not depend on sex [36]. Gajewska and Zawieska, in the questionnaire survey conducted in the children's and their parents' population demonstrated that in the children's opinion, $73.2 \%$ of interviewed learners used the offer of a school shop; however, in the parents' opinion, this percentage amounted to $61.6 \%$. Nearly $9.3 \%$ of parents were not aware that their children do shopping in a school shop. Sweets, juices and confectionery bread turned out to be the most frequently bought food products [21]. Gajda and Jeżewska-Zychowicz demonstrated in their study that $82.2 \%$ of learners used the offer in a school shop. Over half of interviewees declared that they buy food in a school shop (55.9\% of users) 3-4 times a week. About 1/3 of interviewees visited a school shop once or twice during the week [43].

Stankiewicz et al. in their research asked the interviewed children a question: "How often, apart from physical education lesson, do you practise sports in your free time?" They obtained the following answers: $36.7 \%$ of learners claimed that they practise sports every day, $50.5 \%$-at least once a week, and $12.8 \%$ of learners less than once a week, whereas boys significantly more often practised sports (at least once a week) than girls. Moreover, it was proved that $24 \%$ of children aged $10-13$ most willingly spent their free time in front of TV; $18 \%$ of interviewees spent this time on reading books, and $16 \%$ preferred physical activity outdoors [19]. On the other hand, in 2012, Wojtyła demonstrated that only $36 \%$ of learners from the district of Kalisz (Poland) declared that they dedicate time to physical activity every day, the next $36 \%$ of them do physical exercise 4-6 days a week. Fifty-one percent of children [44] practised a daily physical activity in a number of $2 \mathrm{~h}$. The studies conducted by Świderska-Kopacz et al. in a group of Gorzów junior high schools in the school year 2005/2006 demonstrated that only $43.2 \%$ of the interviewed youth did physical exercises in their free time over 4 times a week. $27.3 \%$ of learners did physical exercises once a week, less than once a week or they did not do them at all. Further, as many as $50.7 \%$ of junior high school learners devoted their free time to watching $\mathrm{TV}$, and $49.2 \%$ to games on a computer lasting 4 hours or more within a week [45]. It was demonstrated in the 
international HSBC (Health Behaviour in School-aged Children: A WHO Collaborative Cross-national Study) studies, conducted in 2002, that the average activity time of European teenagers amounted to $3.8 \mathrm{~h}$ a week. The highest level of physical activity was noted in Austria, England, Ireland and Lithuania; however, the lowest was noted in Belgium France, Italy and Portugal. Boys demonstrated higher physical activity than girls. About 34\% of teenagers did not meet the minimal recommendations, at least a 60-min moderate intensity of effort for most of days within a week. These recommendations were met only by $40 \%$ of boys and $27 \%$ of girls [46]. The studies conducted by Rozdziewicz-Gruhn and Pyzik, conducted among 12-year-old children from Polish schools in Lviv, in the Ukraine indicated that only $9 \%$ of boys and $13 \%$ of girls performed physical exercises every day. Twenty-three percent of boys and $17 \%$ of girls did physical exercises 4-5 times a week, respectively $41 \%$ and 30\%-2-3 times a week. Twenty-seven percent of boys and $40 \%$ of girls [47] did physical exercises less than once a week or they hardly ever did any physical exercises. In 2007, Marcysiak et al. conducted the studies among primary and junior high school learners in Ustrzyki Dolne. The studies proved that about $43 \%$ of learners declared that they spent their free time on a football pitch (50\% learners from sports classes and $40 \%$ of learners from general classes), and $22 \%$ were riding a bike. What is worrying, as many as $30 \%$ of interviewed children preferred to spend their time in front of TV or a computer. Only $4 \%$ of learners did not practise any sports [48].

Wojtyła, in their research, demonstrated as well that every fifth learner lives over $3 \mathrm{~km}$ from school. The children most often went to school on foot-54\%. Twentythree percent of respondents were given a lift to school by their parents; however, $10 \%$ of learners came to school by bike. Among the interviewed group of junior high school learners, only $18.3 \%$ declared the existence of common practice of recreational sports in their family. The frequency of taking up such an activity correlated with parents' education (the higher education, the higher its level). Eighty-six percent of interviewed learners participated in extracurricular sports classes. Riding a bike-59\%, playing football-37\%, athletics (running)-28\%, swimming-19\%, dance-16\%, and volleyball-14\% [44] were the most popular sports enumerated by youth. The results of the afore-mentioned COSI (Childhood Obesity Surveillance Initiative) project report that almost half of interviewed 8-year-olds get to school in a passive way, that is, they are transported by their parents in a car or they get to school by public transport. This percentage is higher in the country and concerns $2 /$ 3 of children. Over one-third of children get to school in an active way, on foot or by bike, almost 3 times more in the city than in the country. Every sixth child, on their way to school, combines a walk with a public transport [37]. Waśkiewicz et al. proved, however, that $2 / 3$ of learners took up physical activity not only during physical education lesson but also during curricular classes, and only $1-2 \%$ of interviewed learners did not do physical exercises at all. Despite additional classes, only 34\% of girls and $44 \%$ of boys practised sports and did physical exercises lasting at least 45 min minimum 5 times a week [49]. It was confirmed as well, in the studies conducted by Jodkowska, that only $2 / 3$ of interviewed learners regularly participated in extracurricular physical activities. What is interesting, obese learners [20] participated definitely more rarely in them.

\section{Conclusions}

Based on the obtained questionnaire survey data distributed among parents of school children aged 10-13 living in rural and urban areas of Silesian Province (Poland), it was proved that nearly $44 \%$ of learners are affected by the problem of overweight or obesity. Malnutrition, however, affects as many as $22 \%$ of children. Based on the analyses, we may draw a conclusion that in the investigated population improper dietary habits already preserve in the period of growth and puberty among children. They concern both qualitative and quantitative abnormalities. Children consume inappropriate quantities and proportions of particular food products, important for the suitable development of a young organism. What is worrying, they more and more frequently eliminate fruit and vegetables, high-fibre food products and fish from their diet, replacing them with salty snacks and sweets. Moreover, it was proved that children do not dedicate sufficient time to physical activity within a week. As we could suspect, it was also indicated in the article that the more hours a child spends on physical activity, the lower its BMI level is. Similarly, it was proved that the more frequently children (in the article this correlation concerned only 13-year-old boys) use fast-food bars, the higher their BMI level is. The implementation of large-scale educational programmes for children to schools seems to be incredibly important, but also for parents, to make young people and their parents aware of the rules of appropriate, rational nutrition and the health aftermaths resulting from the degree of nutrition disorders in children.

\section{Acknowledgements}

Not applicable.

\section{Authors' contributions}

PJ and MP-J conceived and designed the study, performed data analysis, wrote the results and discussed the findings. MK and ES contributed to the review of literature and discussed the findings. All authors have read and approved the manuscript. PJ had the final responsibility to submit the manuscript. 


\section{Funding}

Not applicable.

\section{Availability of data and materials} Not applicable.

\section{Declarations}

\section{Ethics approval and consent to participate}

The Bioethical Committee of the Medical University of Silesia in Katowice issued a resolution No. KNW / 0022 / KB1 / 94 / / / 18/19 on consenting to the conduct of a medical and research experiment. The study participants gave their written consent to participate in the study, as recommended by the Bioethics Committee.

\section{Consent for publication}

The oral consent of the study participants was obtained for publication of the results, as agreed by the Bioethics Committee. The authors of the publication also gave only verbal consent to publish the work in the Journal.

\section{Competing interests}

The authors declare that they have no competing interests.

\section{Author details}

'Chair and Department of Descriptive and Topographic Anatomy, Faculty of Health Sciences in Zabrze, Medical University of Silesia in Katowice, UI. Jordana 19, 41-808 Zabrze, Poland. ${ }^{2}$ Chair and Department of Medical and Molecular Biology, Faculty of Health Sciences in Zabrze, Medical University of Silesia in Katowice, Ul. Jordana 19, 41-808 Zabrze, Poland.

Received: 5 November 2020 Accepted: 31 March 2021 Published online: 03 May 2021

\section{References}

1. Zalewska M, Maciorkowska E (2013) The role of dietary education in the population of children and youth. Med Og Nauk Zdr 19(3):375-378

2. Jonczyk P, Potempa M, Kajdaniuk D (2016) Level of nutrition and nutrition disorders as well as characteristics of dietary habits and physical activity among 6-13-year-old children attending selected primary schools in Opole and Silesia provinces in Poland. Pediatr Med Rodz 12(2):177-193. https://doi. org/10.15557/PiMR.2016.0018

3. Przybylska D, Kurowska M, Przybylska P (2012) Overweight and obesity in developmental population. Hygeia Public Health 47(1):28-35

4. Zarzycka D, Szara M, Sroka A (2015) School age obesity-epidemiology, health effects, methods of prevention. Pediatr Endocrinol 14.2.51:79-88

5. Kupczak-Wiśniowska B, Borgosz J, Podsiadło B, Serzysko B, Jędrkiewicz E (2017) Obesity in children-a problem of the contemporary civilization. Pielęgniarstwo XXI wieku 16(58):44-50. https://doi.org/10.1515/pielxxiw-201 7-0007

6. Hassana NE, El Shebinib SM, El-Masrya SA et al (2019) Association between dietary sodium, calcium, saturated fat, and blood pressure in obese Egyptian adolescents. Egypt Pediatr Assoc Gaz 67(1):6. https://doi.org/10.11 86/s43054-019-0007-5

7. Kołłajtis-Dołowy A, Matysiuk E, Boniecka I (2007) Nutritional habits of one selected group of 11-12-year-old children from the city of Białystok. Żywność Technologia Jakość 6(55):335-342

8. Charzewska J, Wajszczyk B, Chabros E et al (2003) Health aspects of the frequency of eating meals - a new perspective on traditional habits. Żyw Człow Metab 30:68-75

9. Wajszczyk B, Charzewska J, Chabros E et al (2004) Change in nutritional habits of the Warsaw adolescents over the recent 30 years of observation. Żyw Człow Metab 31:136-141

10. Cieślik E, Filipiak-Florkiewicz A, Pałasiński J et al (2003) Dietary habits of youth from secondary schools in the Subcarpathian Province. Żyw Człow Metab 30:63-67

11. Frączek B (2003) The characteristics of the way of youth nutrition from comprehensive secondary school graduation classes. Żyw Człow Metab 30: 86-92

12. Kołajtis-Dołowy A, Pietruszka B, Waszczeniuk-Uliczka M et al (2003) The selected dietary behaviours of Warsaw junior high school youth. Żyw Człow Metab 30:182-191
13. Łukasiewicz D, Bachenek T, Kozłowska A (2004) Dietary habits of children and youth based on sales of food products in school shops. Zdr Publ $111(4): 37-41$

14. Olszanecka-Glinianowicz M, Małecka-Tendera E, Klimek K et al (2006) Risk factors of simple obesity in 7-9 year-old Silesian children. Pediatr Endocrinol 2(15):31-38

15. Skop A, Potocki A (2000) Dietary habits and nutrition state of 17-year-old youth of Krakow secondary schools. Leczenie Żywieniowe 2:94

16. Franczyk-Zarow M, Kostogrys RB, Filipiak-Florkiewicz A et al (2009) Dietary habits of the young people from the secondary school. Żyw Człow Metab 36:294-299

17. Ramotowska A, Szypowski W, Kunecka K et al (2017) The assessment of the factors affecting breakfast habits in youth living in Warsaw, the role in obesity prevention. Pediatr Endocrinol 16.1.58:33-40

18. Dzielska A, Kołoło H, Mazur J (2008) Health behaviours of adolescents associated with nutrition in the context of socioeconomic factors - trends between 2002 and 2006. Probl Hig Epidemiol 89(2):222-229

19. Stankiewicz M, Pieszko M, Śliwińska A et al (2010) Obesity, knowledge of diet and healthy behaviors in children and adolescents from small towns and villages - results of polish project of 400 cities. Endocrinol Obes Metab Disord 6:59-66

20. Jodkowska M (2007) Physical activity and sedentary activities in free time. In Oblacińska A, Jodkowska M (eds) Obesity in polish teenagers. Epidemiology, lifestyle, mood. Report from the research on the junior high school students in Poland. Instytut Matki i Dziecka. Zakład Medycyny Szkolnej, Warszawa

21. Gajewska M, Zawieska D (2009) Elementary schoolchildren nutritional behaviors in pupils' and their parents' opinion. Rocz Panstw Zakl Hig 60(4): 347-351

22. Sosnowska-Bielicz E, Wrótniak J (2013) Dietary habits and obesity of children in school and pre-school age. Lubelski Rocznik Pedagogiczny 32:147-165

23. Harnack L, Stang J, Story M (1999) Soft drink consumption among US children and adolescents: nutritional consequences. J Am Diet Assoc 99(4): 436-441. https://doi.org/10.1016/S0002-8223(99)00106-6

24. Woynarowska B, Mazur J (2004) Health behaviours of school youth in Poland: HSBC 2020 research results. Zdrowie Publiczne 114(2):159-167

25. Marcinkowska U, Gałeczka M, Kukowka K et al (2014) Changes in beverage consumption among youth. Probl Hig Epidemiol 95(4):907-911

26. Jonczyk P, Potempa M, Kajdaniuk D (2015) Level of nutrition and nutrition disorders as well as characteristics of dietary habits and physical activity among 6-13-year-old school children in the city of Piekary Śląskie in Poland. Pediatr Med Rodz 11(3):302-314. https://doi. org/10.15557/PiMR.2015.0029

27. Jensen BW, Nichols M, Allender S et al (2012) Consumption patterns of sweet drinks in a population of Australian children and adolescents (20032008). BMC Public Health 12:771

28. Szanecka E, Małecka-Tendera E (2006) Changing nutritional patterns and children's obesity. Endocrinol Obes Metab Disord 2:102-107

29. Stefańska E, Falkowska A, Ostrowska L (2012) Selected nutritional habits of children and teenagers aged 10-15. Rocz Panstw Zakl Hig 63:91-98

30. Cieślik E, Filipiak-Florkiewicz A, Topolska K (2007) The frequency of eating chosen groups of food products and the nutritional state among children ages 13-15. Żyw Człow Metab 36:846-851

31. Szczepańska B, Malczewska-Lenczowska M, Gajewski J (2007) The nutritional habits among teenagers aged 13-15 from competitive sport-oriented school in Warsaw. Żyw Człow Metab 34:578-585

32. Pieszko-Klejnowska M, Stankiewicz M, Niedoszytko M et al (2007) The evaluation of the way of nutrition of junior high school youth living in the country and in a town/city. Pediar Współcz Gastroenterol Hepatol Żywienie Dziecka 9:59-62

33. Jeżewska-Zychowicz M, Łyszkowska D (2003) The evaluation of the selected nutritional behaviours of youth aged 13-15 and their conditionings on the example of urban environment. Żyw Człow Metab 30:572-579

34. Goluch-Koniuszy Z (2010) Evaluation of the nutrition mode in children during the pubertal period with BMI $\leq 5$ percentile in the city of Szczecin. Rocz Panstw Zakl Hig 61(3):307-315

35. Kobus G, Bachórzewska-Gajewska H, Tomaszuk-Kazberuk A et al (2012) What is a bigger problem in teenagers' overweight or underweight? Endocrinol Obes Metab Disord 8:24-31

36. Komosińska K, Wojnarowska B, Mazur J (2001) Health behaviours related to nutrition in polish school-aged children in 1990-1998. Żyw Człow Metab 28. $17-30$ 
37. Fijałkowska A, Oblacińska A, Stalmach M (2017) Overweight and obesity in polish 8-year-old considering biological, behavioural and social conditions. European Childhood Obesity Surveillance Initiative (COSI). IMID, Warszawa

38. French SA, Story M, Neumark-Sztainer D et al (2001) Fast food restaurant use among adolescents: associations with nutrient intake, food choices and behavioral and psychosocial variables. Int J Obes 25:1823-1833

39. Braithwaite I, Stewart AW, Hancox RJ, Stewart AW, Hancox RJ, Beasley R, Murphy R, Mitchell EA, ISAAC Phase Three Study Group., ISAAC Phase Three Study Group (2014) Fast-food consumption and body mass index in children and adolescents: an international cross-sectional study. BMJ Open 4(12):e005813. https://doi.org/10.1136/bmjopen-2014-005813

40. Rasmussen M, Krolner R, Svastisalee CM et al (2008) Secular trends in fruit intake among Danish schoolchildren, 1996 to 2006: changing habits or methodological artefacts? Int J Behav Nutr Phys Act 5(1):6-14. https://doi. org/10.1186/1479-5868-5-6

41. McGuire S (2013) State indicator report on fruits and vegetables. Centers for Disease Control and Prevention, Atlanta, GA. Adv Nutr 4(6):665-666. https:// doi.org/10.3945/an.113.004598

42. Weichselbaum E, Buttriss JL (2014) Diet, nutrition, and schoolchildren: an update. Nutr Bull 39(1):9-73. https://doi.org/10.1111/nbu.12071

43. Gajda R, Jeżewska-Zychowicz M (2010) Nutritional behaviours of adolescents living in the Świętokrzyskie voivodeship. Probl Hig Epidemiol 91(4):611-617

44. Wojtyła K (2012) Health behaviours of primary school children and their parents on the example of $5^{\text {th }}$ and $6^{\text {th }}$ grade students from the district of Kalisz and the commune of Kalisz. Doctoral dissertation. Uniwersytet Medyczny im. Karola Marcinkowskiego w Poznaniu, Poznań

45. Świderska-Kopacz J, Marcinkowski J, Jankowska K (2008) Health behaviour of secondary school pupils and its chosen determinants. Part V. physical activity. Probl Hig Epidemiol 89(2):246-250

46. Currie C, Nic Gabhainn S, Godeau E (2009) International HBSC network coordinating committee. The health behaviour in school-aged children: WHO collaborative cross-national (HBSC) study: origins, concept, history, and development 1982-2008. Int J Public Health 54(S2):131-139. https://doi. org/10.1007/s00038-009-5404-x

47. Rozdziewicz-Gruhn J, Pyzik M (1999) Evaluation of pro- and anti-salubrious behaviour by polish schools from Lviv in the Ukraine. Borgis Nowa Medycyna 7:10-14

48. Marcysiak M, Ciosek A, Żywica M et al (2009) Dietary behavior and physical activity among pupils of sports and general class in Ustrzyki Dolne. Probl Pielęg 17(3):216-222

49. Waskiewicz A, Slonska Z, Drygas W (2009) Can health behaviors of polish adolescents foster prevalence of overweight and obesity? Roczn PZH 60: $341-345$

\section{Publisher's Note}

Springer Nature remains neutral with regard to jurisdictional claims in published maps and institutional affiliations.

\section{Submit your manuscript to a SpringerOpen ${ }^{\circ}$ journal and benefit from:}

- Convenient online submission

- Rigorous peer review

- Open access: articles freely available online

- High visibility within the field

- Retaining the copyright to your article

Submit your next manuscript at $\boldsymbol{\nabla}$ springeropen.com 